\title{
The development study of Karaha-Talaga Bodas geothermal field using numerical simulation
}

\author{
Sutopo ${ }^{1,2}$, Welly Prabata ${ }^{* *}$ and Heru Berian Pratama $a^{1,2}$
}

\author{
*Correspondence: \\ t.wellyp@gmail.com \\ ${ }^{1}$ Geothermal Engineering \\ Master Program, Institut \\ Teknologi Bandung, Jl. \\ Ganesha 10, Bandung 40132, \\ Indonesia \\ Full list of author information \\ is available at the end of the \\ article
}

\begin{abstract}
A numerical simulation study of the Karaha-Talaga Bodas geothermal field was carried out to assess the resource and to analyze and predict reservoir behavior under various development scenarios. The three-dimensional natural state model of the Karaha-Talaga Bodas field has been validated with the pressure and temperature of seven wells and the conceptual model of the field. This study explores the application of an experimental design and response surface method for capturing relevant uncertainties existing in the geothermal reservoir simulation; thus, the results of this approach are the assessment of probabilistic resources. The power potential calculated from reservoir simulation results is used to develop proxy equations and then Monte Carlo simulations were applied on proxy models to produce probabilistic distributions of power potential output. Based on Monte Carlo Simulation, the probabilistic power capacity of Karaha-Talaga Bodas field is $120 \mathrm{MW}$ as P50. This model is also used to estimate potential field responses based on two different field development scenarios. Forecasting two development scenarios shows that the best development is $60 \mathrm{MW}$ with a make-up well strategy drilled in the deep-water zone. This scenario requires the number of production, injection, and make-up wells to be 11,3 , and 4 , respectively. The reservoir response shows that the pressure drop is between 0.2 and 0.6 bar/year while the temperature drop is $2-14^{\circ} \mathrm{C}$ for 30 years.
\end{abstract}

Keywords: Karaha-Talaga Bodas, Numerical reservoir simulation, Natural state, Experimental design, Resource assessment, Development scenarios

\section{Background}

The Karaha-Talaga Bodas (K-TB) geothermal field was declared commercially operated in April 2018 with a capacity of 30 MW. This geothermal field is located on a ridge trending north-south to the north of Mount Galunggung, West Java, Indonesia (Fig. 1). The first exploration program of the K-TB geothermal field was conducted in December 1994 by Karaha Bodas Company (KBC). Nineteen shallow-slim and twelve full-sized wells had been drilled by 1998, and by 2010, 14 total full-sized wells had been drilled in the K-TB field (GeothermEx 1998).

The K-TB field consists of two parts: the northern part (the Kawah Karaha area) and the southern part (the Talaga Bodas area). The K-TB field is estimated to have large geothermal potential with a partially steam-dominated system and temperatures reaching

(c) The Author(s) 2019. This article is distributed under the terms of the Creative Commons Attribution 4.0 International License (http://creativecommons.org/licenses/by/4.0/), which permits unrestricted use, distribution, and reproduction in any medium, provided you give appropriate credit to the original author(s) and the source, provide a link to the Creative Commons license, and indicate if changes were made. 


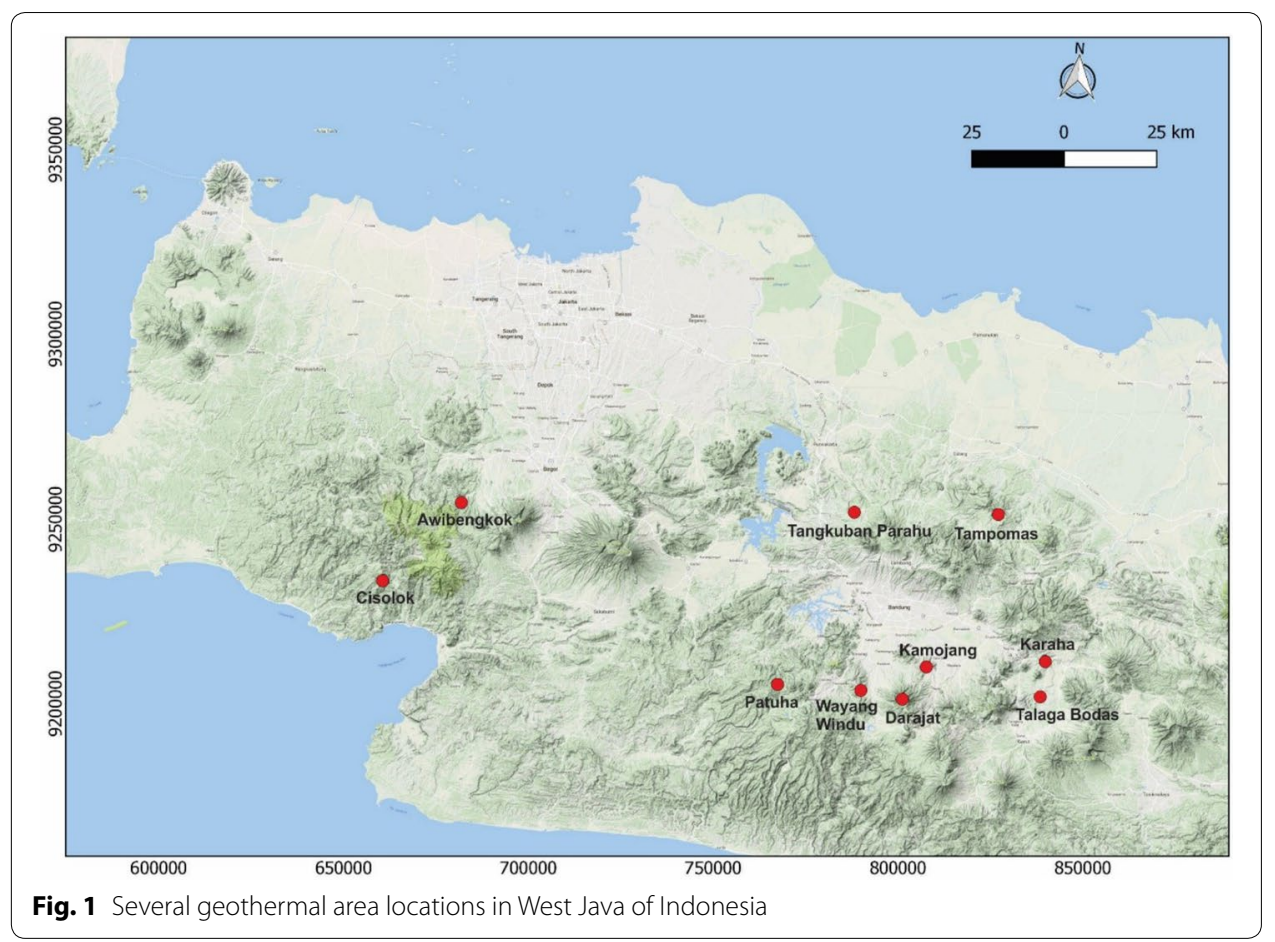

$350{ }^{\circ} \mathrm{C}$ (Allis et al. 2000; Allis and Moore 2000; Powell et al. 2001). These previous studies identified parts of the K-TB field geothermal system in the form of low permeability, vapor-dominated reservoir zones in the south at shallow depth underlying a fluid-dominated zone.

The biggest challenge faced in building a numerical model of geothermal reservoirs is the existence of several parameters with a high degree of uncertainty, such as coverage area and reservoir thickness, porosity, permeability, rock density, reservoir temperature, and water saturation. The uncertainty of these variables has an impact on the level of confidence in estimating the potential energy resources of a field and forecasting the performance of the reservoir. Therefore, to overcome this problem, the probabilistic approach needs to be performed using an experimental design to take a range of potential values of the uncertainty of reservoir parameters (Quinao and Zarrouk 2014, 2015, and Quinao and Zarrouk 2018; Pasikki et al. 2016; Ashat and Pratama 2017). The principle of the experimental design method is to systematically and simultaneously test the response of several parameters to the model so that a parameter sensitivity analysis can be applied to the model.

The aim of this study is to develop a numerical simulation model of the K-TB field that has an important role to assess resources, predict reservoir behavior and its performance. The developed natural-state reservoir model was calibrated by comparing the measured temperature and pressure profiles from seven wells and the conceptual model of the field afterward used to assess its resource using an experimental design method. Furthermore, the numerical model that has been developed was used to predict reservoir performance to obtain appropriate field development and reservoir management strategies for the sustainability of K-TB geothermal field production. The TOUGH2 simulator is used by applying state equations for water and steam (EOS1). 


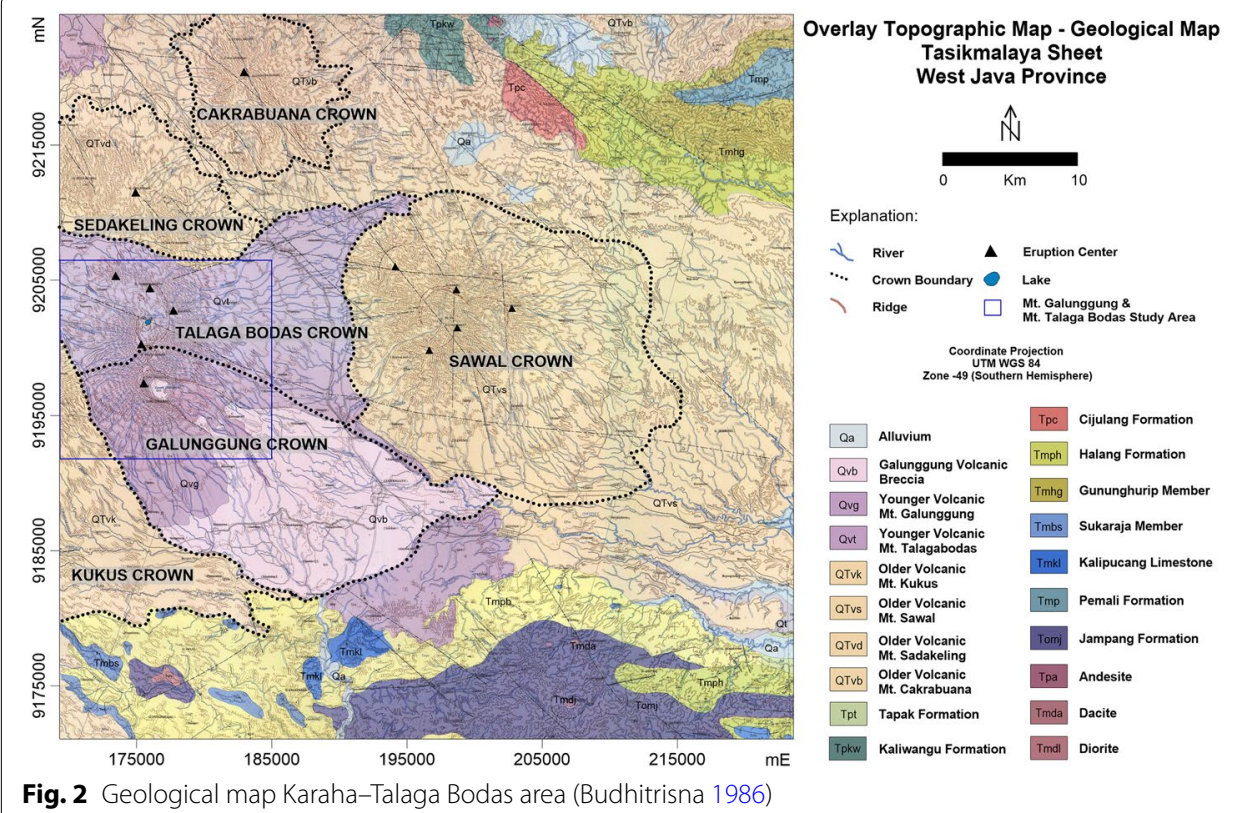

\section{Geological review}

The $\mathrm{K}-\mathrm{TB}$ region is located at the eastern end of the chain of young volcanic complexes that dominate the topography of West Java and host a number of geothermal fields, which are currently in the commercial operation stage. Patuha, Wayang Windu, Kamojang, and Darajat fields are all located west of K-TB area within $150 \mathrm{~km}$ (Fig. 1).

Based on the regional geological map of the Tasikmalaya region (Budhitrisna 1986), see Fig. 2, the northern part is an old volcanic formation consisting of volcanic breccia, andesitic to basalt breccia tufa and lava flows (Moore et al. 2002a, b, c). This rock is thought to be the result of the eruption of Sadakeling Mountain at the age of the Pleistocene. Meanwhile, the southern part is young volcanoes that are thought to originate from Mount Talaga Bodas with the age of the Late Pleistocene to the Holocene. Evidence from radiometric dating indices of the $\mathrm{K}-\mathrm{TB}$ rock surface system shows the range between 1.75 and 0.32 m.y., with the youngest dates being in the Talaga area (Allis et al. 2000).

The K-TB geothermal field is located on a ridge trending almost north of the south, perpendicular to the minimum main stress direction (N98E) as stated by (Nemcok et al. 2001). GeothermEx (1998) has reported the appearance of several faults showing in the K-TB field using aerial interpretation, as shown in Fig. 3. As stated Nemcok et al. (2004), Nemcok et al. 2007), fluid flow in the reservoir is mainly controlled by faults; therefore, the southern and central regions have better permeability (Brehme et al. 2016; PerezFlores et al. 2017). Furthermore, Moore et al. 2000, 2002a, b, c, Moore et al. 2004 explain that based on petrographic studies and fluid inclusions from several drill samples, the evolution of the liquid dominated system at high temperatures turned into steam dominated. A liquid dominated system may be formed as a result of diorite intrusions that break through to a depth of under $3 \mathrm{~km}$ near the Talaga Bodas area. Though the transition from a high-temperature liquid dominated system to steam-dominated conditions 


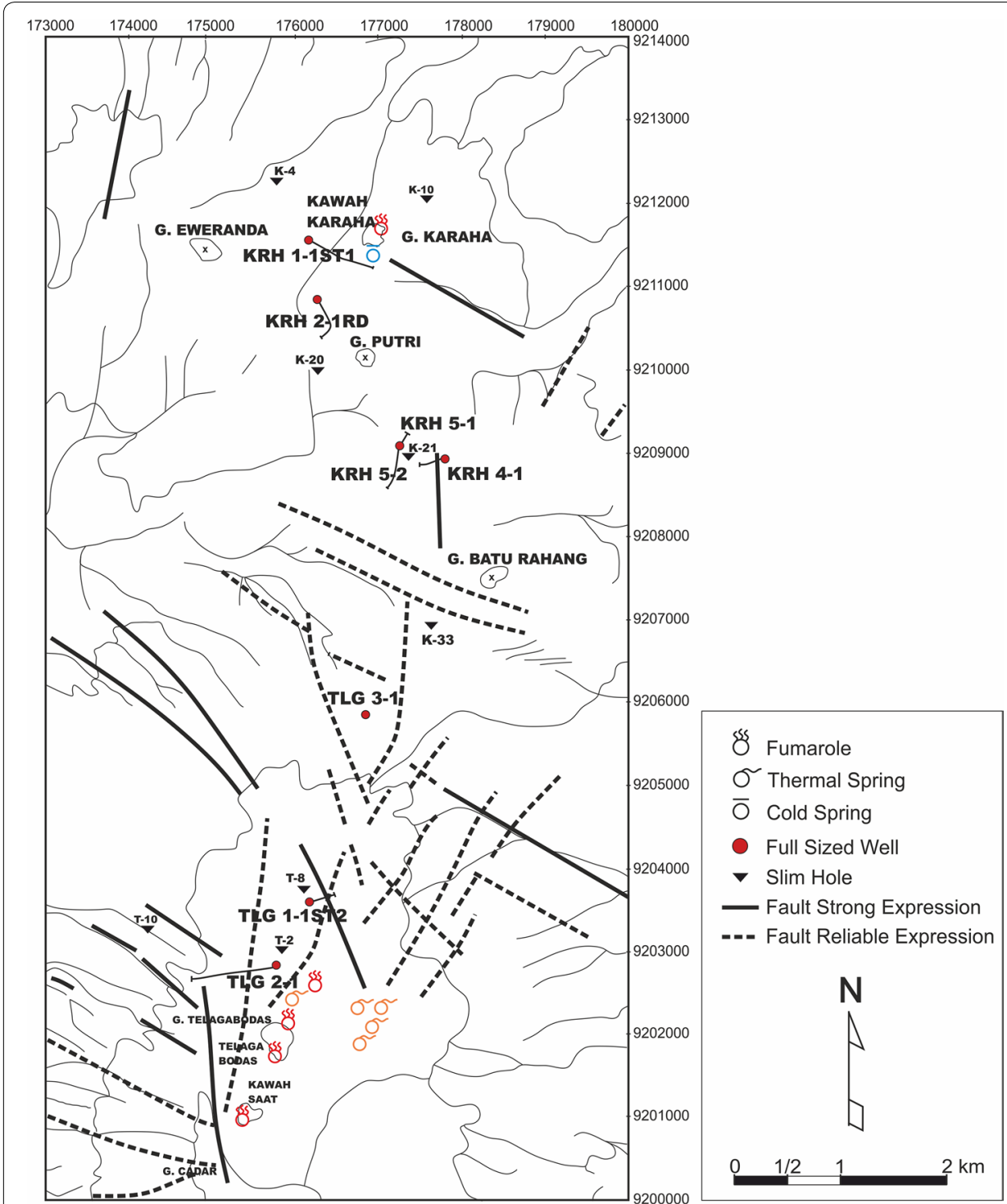

Fig. 3 The fault distribution map in Karaha-Talaga Bodas area (Geothermex 1998)

is hypothesized to be related to the flank collapse that occurred on Mount Galunggung around 4200 years ago (Moore et al. 2002a, b, c, 2003, 2008, Moore 2012), as described by Bronto (1989).

\section{The fluid geochemistry}

The thermal manifestations found in the Karaha are in the form of hot springs, while in the Talaga Bodas there is a fumarole in the Saat Crater, acidic lake water, and springs of sulfide-bicarbonate with neutral to acidic water properties (see Table 1 and Fig. 4). Increased concentrations of $\mathrm{F}^{-}, \mathrm{Cl}^{-}$, and $\mathrm{SO}_{4}{ }^{2-}$ in lake water indicate that the fluid in this area is affected by magmatic gas (Nemcok et al. 2007) which showed an upflow zone of the geothermal system. Based on the fluid inclusion analysis results, K-TB has different hydrothermal environment conditions where fluid trapped are enriched in 
Table 1 Temperature, $\mathrm{pH}$ and chemical composition of surface manifestation sample of $\mathrm{K}$ TB field. Modified from GeothermEx (1998)

\begin{tabular}{|c|c|c|c|c|c|c|}
\hline Map code & Location & Temp ${ }^{\circ} \mathrm{C}$ & $\mathrm{pH}$ & $\mathrm{HCO}_{3}$ & $\mathrm{SO}_{4}$ & $\mathrm{Cl}$ \\
\hline \multicolumn{7}{|l|}{ Karaha area } \\
\hline KR-1 & Jenkin's Seep & 22 & 3.8 & $<1$ & 27 & 5 \\
\hline KR-2 & Kp.Bakom spring & 22 & 3.8 & $<1$ & 184 & 4 \\
\hline KR-3 & Karaha fumarole & 96 & 2.3 & $<1$ & 965 & 3 \\
\hline KR-4 & Karaha fumarole & 91 & 6.6 & 33 & 208 & 11 \\
\hline KR-5 & Kp.Ciselan spring & 22 & 7.2 & 41 & 6 & 3 \\
\hline KR-6 & Sawah Cipanas spring & 38 & 6.3 & 167 & 38 & 6 \\
\hline KR-7 & Karaha mudpot & 92 & 6.4 & 33 & 370 & 4 \\
\hline KR-A & Kp.Bakom spring & - & - & - & - & - \\
\hline $\mathrm{KRH}-03$ & Karaha fumarole & Steam & - & - & - & - \\
\hline \multicolumn{7}{|c|}{ Talaga Bodas area } \\
\hline FM-3 & Warm spring & 48 & 2.9 & $<2$ & 346 & 824 \\
\hline FM-4 & Freshwater spring & - & - & - & - & - \\
\hline KBC & $\mathrm{KBC}$ spring & 47 & 2.3 & $<2$ & 584 & 4680 \\
\hline TEL-1 & Talaga Bodas lake & 72 & 3.8 & $<1$ & 216 & 62 \\
\hline TEL-2 & Talaga Bodas fumarole & 93 & 2.8 & $<1$ & 2050 & 16 \\
\hline TEL-3 & Talaga Sodas mudpot & 90 & 0.8 & $<1$ & 5016 & 3072 \\
\hline TEL-4 & Resurgent fumarole & 72 & 1.8 & $<1$ & 1560 & 26 \\
\hline TEL-5 & Cipanas spring & 61 & 2.8 & $<1$ & 622 & 288 \\
\hline TEL-6 & Cikahuri spring & 48 & 2.7 & $<1$ & 438 & 2129 \\
\hline TEL-7 & Ciateul spring & 43 & 2.3 & $<1$ & 298 & 322 \\
\hline TEL-8 & Cikajaya spring & 49 & 1.8 & $<1$ & 614 & 2204 \\
\hline TEL-9 & Fire Mountain spring & 46 & 3.9 & 58 & 221 & 5 \\
\hline TEL-10 & Mixed-Fe (iron) spring & 33 & 5.5 & 99 & 360 & 172 \\
\hline TEL-A & Kawah Saat & Steam & - & - & - & - \\
\hline TEL-B & Talaga Bodas fumarole & Steam & - & - & - & - \\
\hline \multicolumn{7}{|c|}{ Outside concession area } \\
\hline TAK-1 & Kp.Sumur (W of Karaha project area) & 26 & 6.3 & 55 & 8 & 7 \\
\hline TAK-2 & Kp.Cinta (SW corner of Karaha project area) & 26 & 6.3 & 55 & 8 & 7 \\
\hline TAK-3 & Panoyana (E of Karaha project area) & 46 & 6.1 & 656 & 2 & 11 \\
\hline TAK-4 & Kp.Salaa (NE of Karaha project area) & 22 & 2.5 & 0 & 191 & 11 \\
\hline TAK-5 & Kp.Salaa (NE of Karaha project area) & 23 & 6.1 & 44 & 3 & 5 \\
\hline TAK-6 & Cipeles (NW of concession boundary) & 60 & 6.7 & 980 & - & 131 \\
\hline TAK-7 & Galunggung (S of concession boundary) & 65 & 6.7 & 545 & 1110 & 194 \\
\hline TAK-8 & Kp.Cipacing (E edge concession area) & 50 & 6.4 & 1080 & - & 167 \\
\hline TAK-9 & Tanjungkerta (E of concession area) & 38 & 6.4 & 703 & - & 224 \\
\hline TAK-10 & Cicilap (E of concession boundary) & 40 & 6.4 & 1070 & - & 462 \\
\hline TAK-11 & Panoyana (E side concession area) & 43 & 6.3 & 881 & 2 & 103 \\
\hline
\end{tabular}

magmatic gas, whereas fluid in central area has neutral and meteoric in origin characterization (Moore et al. 2002a, b, c; Dilley and Moore 2015). Chloride-bicarbonate water at the location of TAK-8, TAK-9, and TAK-10 occurs due to dilution of liquid chloride by groundwater or bicarbonate water during lateral flow (Nicholson 1993, Armannsson 2012).

Powell et al. (2001) described an analysis of fluid chemistry from the wells during rig and flow tests, spring, and fumaroles. Based on gas $\mathrm{CO}_{2}-\mathrm{H}_{2}$ geothermometers, temperature reservoir of $\mathrm{K}-\mathrm{TB}$ field ranges from 225 to $310{ }^{\circ} \mathrm{C}$ which is similar to measured 


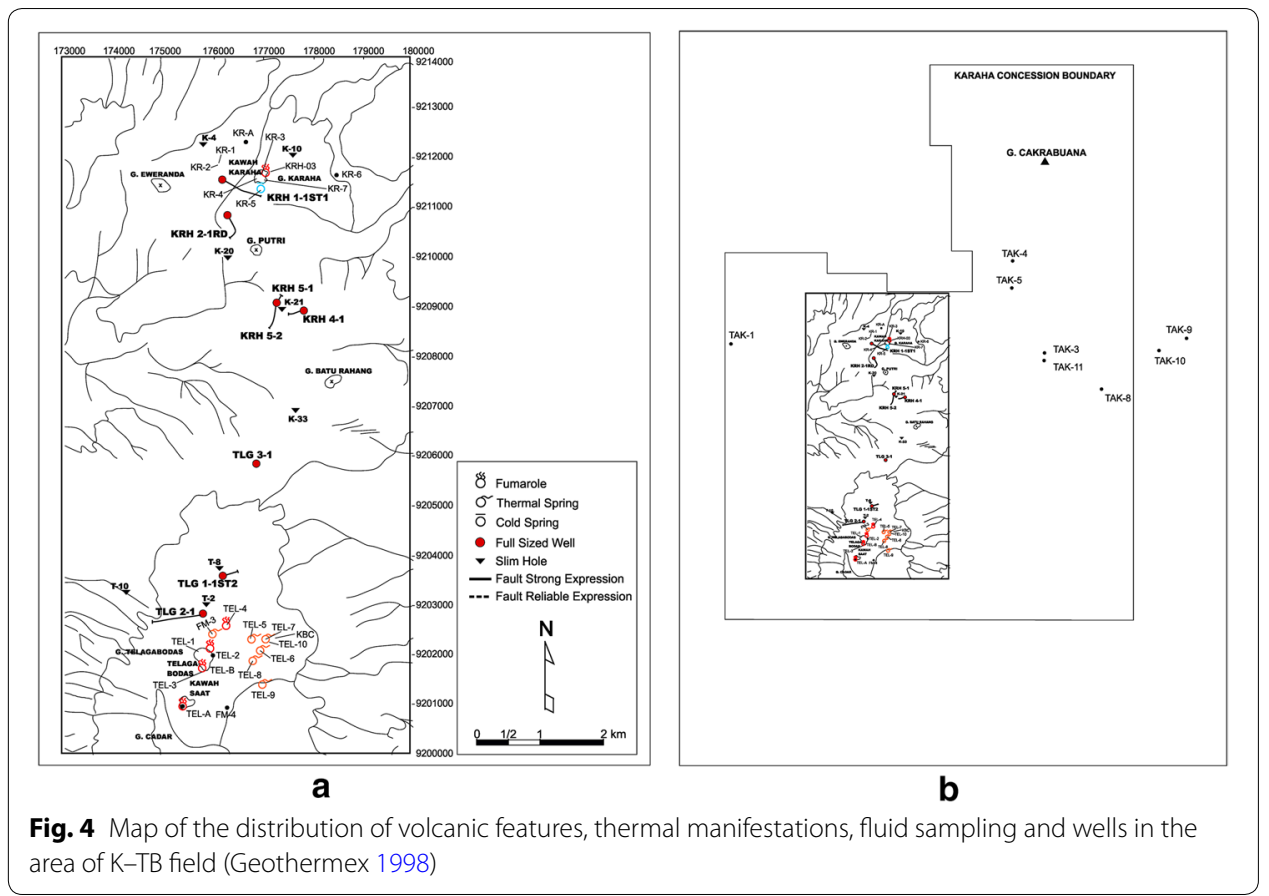

temperatures in the wells. The fluid sample at Talaga shows a younger system with lower maturity level while the Karaha area shows an older system with higher maturity. The geothermal water has high $\mathrm{Cl}$ content relative to $\mathrm{Li}$ and $\mathrm{B}$ indicating that the water comes from the old hydrothermal system and they migrate from the old basement rock (Strelbitskaya et al. 2015).

\section{Geophysical section}

Gravity and MT data of the K-TB area show a high anomalous value that extends from Talaga Bodas to Karaha Crater. This anomaly then increases in the south and forms a radially symmetrical pattern. Tripp et al. (2002) and Raharjo et al. (2002) have modeled these anomalous patterns into two geometries. The first geometry is vertical intrusion which reaches a relatively shallow depth $(<3 \mathrm{~km})$ under Talaga Bodas. The second geometry is concordant intrusion which extends to approximately $10 \mathrm{~km}$ to the north at a depth of $2400 \mathrm{~m}$. This intrusion is modeled as diorite which is thought to be a heat source of the K-TB geothermal system (Moore et al. 2002b, 2004).

\section{Well data}

KBC has successfully drilled nine full-sized wells. Based on the drilling and well test reports, only five wells were categorized as productive, with depths ranging from 1854 to 3076 m. KRH 1-1, KRH 2-1, and KRH 3-1 are classified as non-commercial wells, while KRH 4-1, KRH 5-1 and all wells in Talaga Bodas area are classified as commercial well. Seven wells of K-TB field were used for model validation, four wells as representative of Karaha area (KRH 1-1, KRH 2-1, KRH 4-1, and KRH 5-1) and three wells as representative of Talaga Bodas area (TLG 1-1, TLG 2-1, TLG 3-1). Referring to productive well analysis, the characteristics of each well include maximum temperature, reservoir 
Table 2 The characterization of seven wells in K-TB field

\begin{tabular}{llll}
\hline Well & $\boldsymbol{T}_{\max }\left({ }^{\circ} \mathbf{C}\right)$ & $\begin{array}{l}\text { Reservoir thickness } \\
(\mathbf{m})\end{array}$ & Reservoir fluid phase \\
\hline TLG1-1 & 289 & 1328 & Superheated steam \\
TLG2-1 & 350 & 1175 & Superheated steam \\
TLG3-1 & 286 & 1493 & Steam zone underlying deep liquid reservoir \\
KRH1-1 & 235 & 1592 & Compress liquid \\
KRH2-1 & 269 & 1417 & Compress liquid \\
KRH4-1 & 263 & 1504 & Steam zone underlying deep liquid reservoir \\
KRH5-1 & 272 & 1924 & Steam zone underlying deep liquid reservoir \\
\hline
\end{tabular}

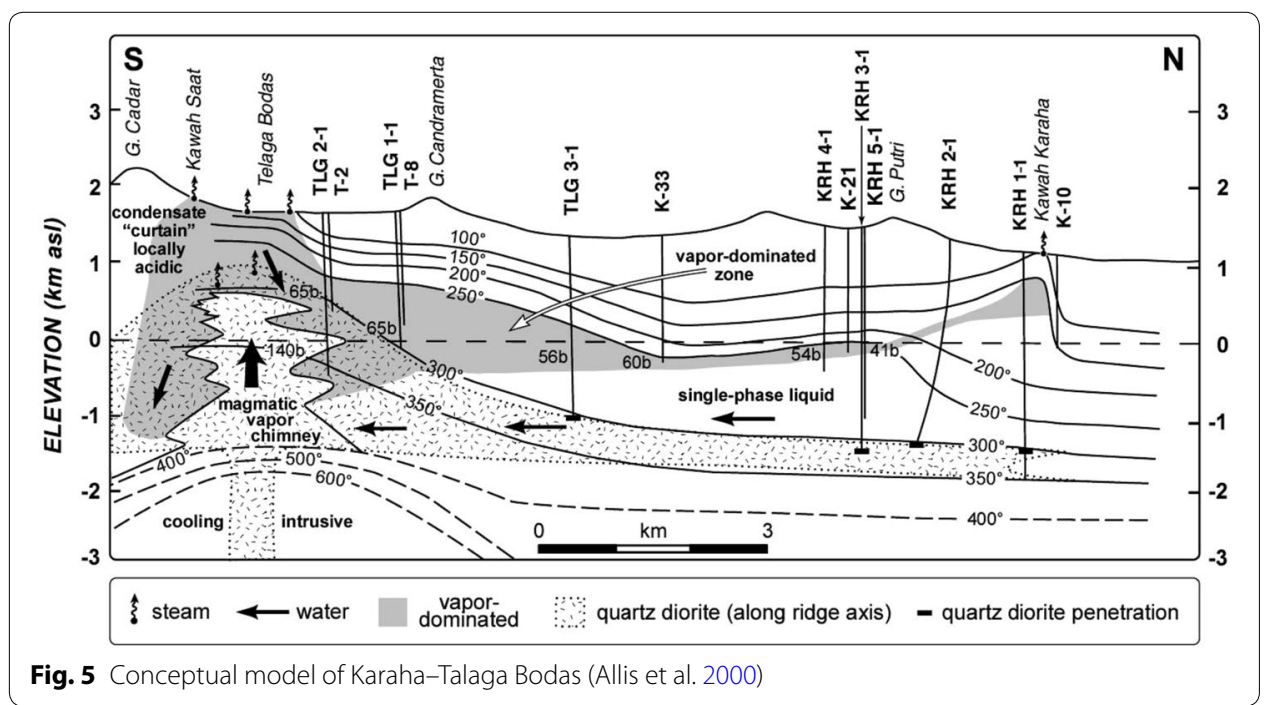

thickness and reservoir fluid phase shown in Table 2. Reservoir thickness was estimated from the temperature profiles. The minimum depth was considered at the level of top of the convective layer and the maximum depth was considered to extend the $500 \mathrm{~m}$ from bottom of the wells. Determination of fluid phase in the reservoir was analyzed by the boiling point with depth curve.

\section{Conceptual model}

The numerical simulation is based on a conceptual model for the K-TB geothermal system that explains the main characteristics of the system (Allis et al. 2000). Figure 5 shows the conceptual model for the cross section of south-north. Heat source locations were estimated to be beneath Saat Crater and Talaga Bodas Lake. The upflow zone is located in Talaga and Karaha which is shown by the presence of several thermal manifestations such as fumaroles, Talaga Bodas acid lake, thermal springs with high content of $\mathrm{SO}_{4}$ and $\mathrm{Cl}$, while the outflow of the system is located in the east of concession boundary (Pamoyanan, Cicilap, dan Cipancing), see Fig. 4b, which is characterized by chloridebicarbonate water and low temperature of thermal manifestation, see Table 1.

$\mathrm{K}-\mathrm{TB}$ geothermal field is categorized as high-temperature reservoir. The liquid reservoir is overlaid by a vapor zone. The highest temperature and pressure are found in well TLG 2-1, is $350^{\circ} \mathrm{C}$. The south area has the thickest steam zone. The steam zone becomes 


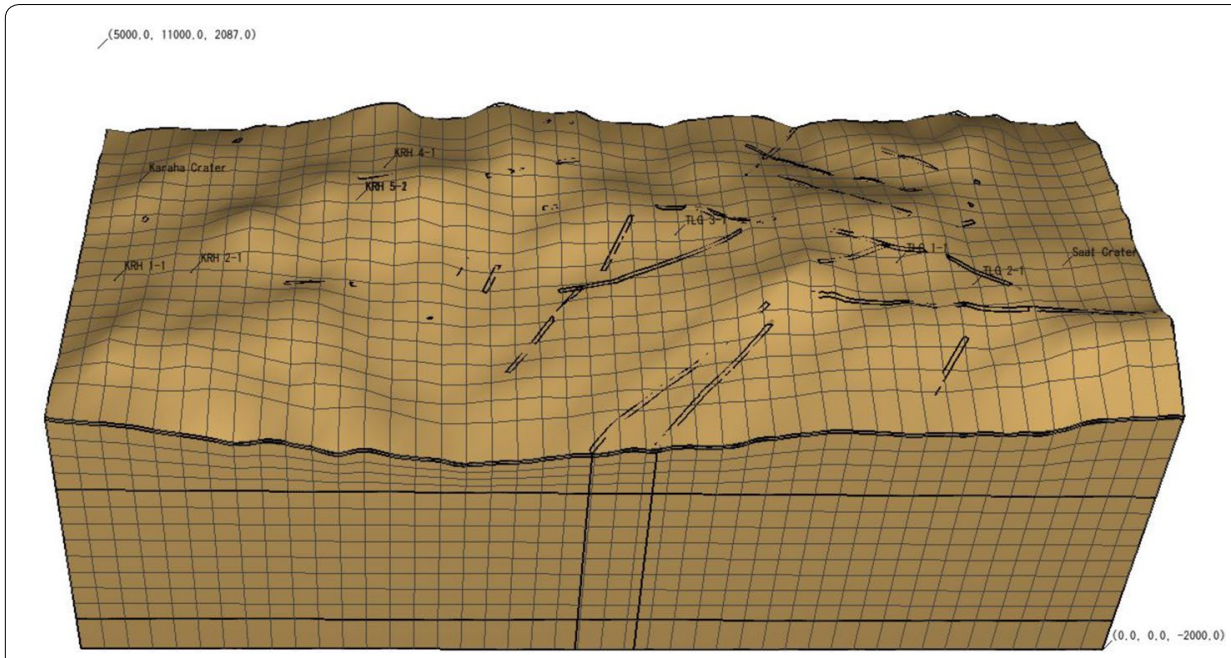

Fig. 6 3-D grid system model of Karaha-Talaga Bodas field

thinner towards the north and its northern limit lies between wells KRH 2-1 and KRH $1-1$.

\section{Methods}

The K-TB geothermal field was simulated using TOUGH2 for modelling multi-dimensional, multiphase flow and heat transport in porous and fractured media (Pruess et al. 1999). The modelling was performed using equation of state module (EOS1) for pure water.

\section{Gridding and layering}

The numerical model covers a total area $55 \mathrm{~km}^{2}$, from 174000 to $179000 \mathrm{E}$ and 9201000 to $9212000 \mathrm{~N}$. The maximum elevation of surface model reaches 2087 m.a.s.l and the bottom of the model was set to $-2000 \mathrm{~m}$ below sea level. The grid block size consists of the smallest $250-250 \mathrm{~m}$ (reservoir) to the most significant 250-500 $\mathrm{m}$ (boundary). The optimization of mesh size was reported by Verma and Arias (2014) as $0.25 \mathrm{~km}$ for a 2-D mesh. The model was constructed in single porosity with a rectangular grid and consists of 14 layers. The model was divided into four rock types that are surface, caprock, reservoir, and basement. The surface layer has a thickness of $10 \mathrm{~m}$, the caprock thickness is up to $1300 \mathrm{~m}$, the reservoir of $2000 \mathrm{~m}$ and the basement of $500 \mathrm{~m}$. The model was built using TOUGH2 software to solve a numerical model of flow and transport using integral finite difference. EOS 1 was chosen for the equation of state. The total number of elements or blocks is 11,088. A 3D view of the model can be seen in Fig. 6 .

\section{Material properties}

In the natural state modelling, the calibration of the location and magnitude of the deep inflows and the selection of material properties plays an important role. The most important property to give the best match in the natural state calibration process is the permeability structure (Omagbon and O'Sullivan 2011). Permeability structure determines the 
Table 3 The type and physical properties of rocks used to build a reservoir simulation model of the K-TB geothermal field

\begin{tabular}{|c|c|c|c|c|c|}
\hline \multirow{2}{*}{$\begin{array}{l}\text { Rock type } \\
\text { SRF1 }\end{array}$} & \multirow{2}{*}{$\begin{array}{c}\text { Description } \\
\text { Surface }\end{array}$} & \multicolumn{3}{|c|}{ Permeability $k_{x^{\prime}} k_{y^{\prime}} k_{z}(\mathrm{mD})$} & \multirow{2}{*}{$\begin{array}{l}\varphi \\
0.05\end{array}$} \\
\hline & & 0.4 & 0.4 & 0.2 & \\
\hline SRF2 & Surface & 0.9 & 0.9 & 0.5 & 0.05 \\
\hline SRF3 & Surface & 10 & 10 & 5 & 0.05 \\
\hline SRF4 & Surface & 1 & 1 & 0.8 & 0.05 \\
\hline CPR & Caprock & 0.001 & 0.001 & 0.001 & 0.05 \\
\hline RSV1 & Reservoir & 100 & 100 & 50 & 0.07 \\
\hline RSV2 & Reservoir & 80 & 80 & 40 & 0.07 \\
\hline RSV3 & Reservoir & 20 & 20 & 10 & 0.07 \\
\hline RSV4 & Reservoir & 1 & 1 & 0.8 & 0.07 \\
\hline RSV5 & Reservoir & 10 & 10 & 4 & 0.07 \\
\hline RSV6 & Reservoir & 20 & 20 & 8 & 0.07 \\
\hline BON1 & Boundary & 0.0001 & 0.0001 & 0.0001 & 0.05 \\
\hline BON2 & Boundary & 0.01 & 0.01 & 0.01 & 0.05 \\
\hline BON3 & Boundary & 0.001 & 0.001 & 0.001 & 0.05 \\
\hline BASE & Basement & 15 & 15 & 4 & 0.05 \\
\hline HEAT & Heat & 1 & 1 & 0.7 & 0.05 \\
\hline FLT1 & Fault & 10 & 10 & 5 & 0.1 \\
\hline FLT2 & Fault & 40 & 40 & 20 & 0.1 \\
\hline FLT3 & Fault & 0.08 & 0.08 & 0.04 & 0.05 \\
\hline FLT4 & Fault & 8 & 8 & 4 & 0.1 \\
\hline FLT5 & Fault & 20 & 20 & 10 & 0.1 \\
\hline
\end{tabular}

direction of fluid movement which results in influencing the temperature distribution in the reservoir.

Table 3 displays all of the permeability and porosity materials that were used in the model. The permeability value ranges from 0.0001 to $100 \mathrm{mD}$. Other material properties such as density, specific heat and wet heat conductivity are specified to $2600 \mathrm{~kg} / \mathrm{m}^{3}$, $1000 \mathrm{~J} /(\mathrm{kg} \mathrm{K})$ and $2 \mathrm{~W} /(\mathrm{m} \mathrm{K})$, respectively. The distribution of material properties can be seen in Fig. 7. 


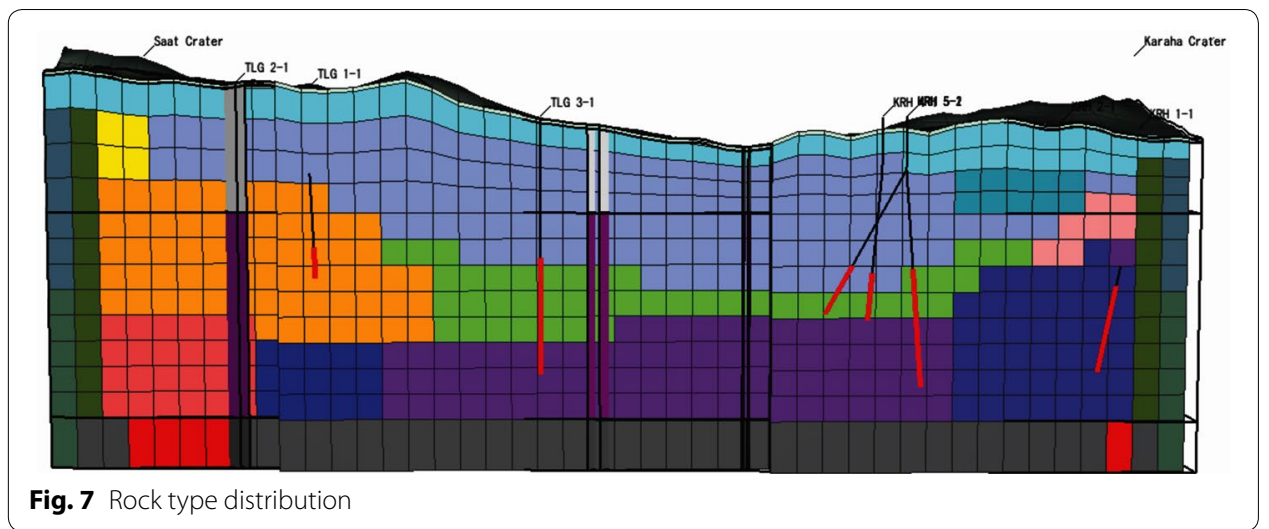

Initial and boundary conditions

Top boundary

The top layer (SRF1-SRF4) represents the atmospheric layer. Atmospheric condition is assigned to 1 bar and $20{ }^{\circ} \mathrm{C}$. The volume factor of the atmospheric layer was also set to $1.0 \mathrm{E}+20$ that this layer cannot be affected by heat exchange from the reservoir. The properties of the top layers (SRF1-SRF4) can be seen in Table 3.

\section{Bottom boundary}

In the calibration process, adjustments to the amount of mass recharge, heat flow, and its location are made based on the ability of the model to accurately reproduce well pressure and temperature data. High-temperature fluid recharge with the enthalpy of $1650 \mathrm{~kJ} / \mathrm{kg}$ and mass rate $5 \mathrm{~kg} / \mathrm{s}$ was assigned in the bottom of the model (BASE). The location of deep recharge is in the north area between KRH 1-1 and KRH 2-1 wells. The heat source (HEAT) was also assigned in the bottom model using 16 blocks in the southern area with maximum pressure and temperature reservoir of 165 bars, $350{ }^{\circ} \mathrm{C}$ and volume ratio set high to neglect the thermodynamic exchange which occurred during the natural process. The properties of the bottom boundary (BASE and HEAT) can be seen in Table 3.

\section{Side boundary}

All side boundaries are assumed to be a no-flow boundary that heat or mass cannot flow in or out into the system. Pressure and temperature of the side boundary were used hydrostatic pressure and normal temperature gradient to represent environment condition. The delineation of the reservoir side boundaries is based on the distribution of well location and the analysis of MT data. The properties of the side boundary (BON1BON3) can be seen in Table 3.

\section{Internal boundary}

Several faults have a presence in K-TB field (Fig. 3), the faults are represented by internal boundaries. Figure 8 shows the 3D model of faults that were used in the model, material properties of faults (FLT1-FLT5) were assigned to the reservoir model have porosity and permeability as shown in Table 3. 


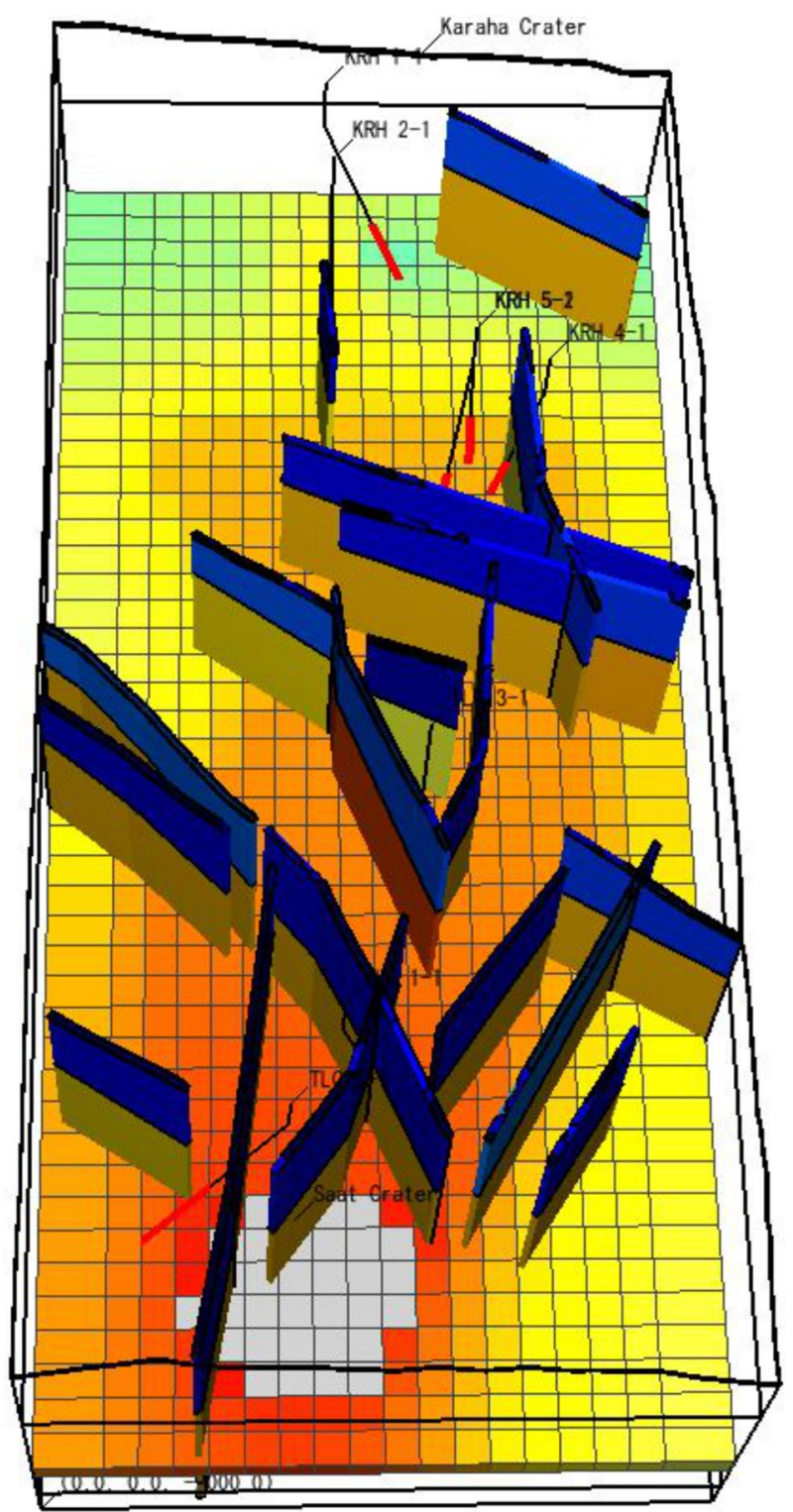

Fig. 8 3-D fault model

\section{Results and discussion}

\section{Natural state}

During the natural state calibration processes, the model was run until a steady-state condition was reached. Several validation processes have been carried out to check the reliability of the model, such as pressure and temperature matching, steam zone presence, and heat and mass flow direction. To obtain a good fit between the model and actual measurement, several steps were enacted using an iterative process such as a change in permeability value, determining the amount and enthalpy of deep mass recharge, adjust the location of deep recharge, and block refinement using a new rock type to improve matching process (Sumantoro et al. 2015). 


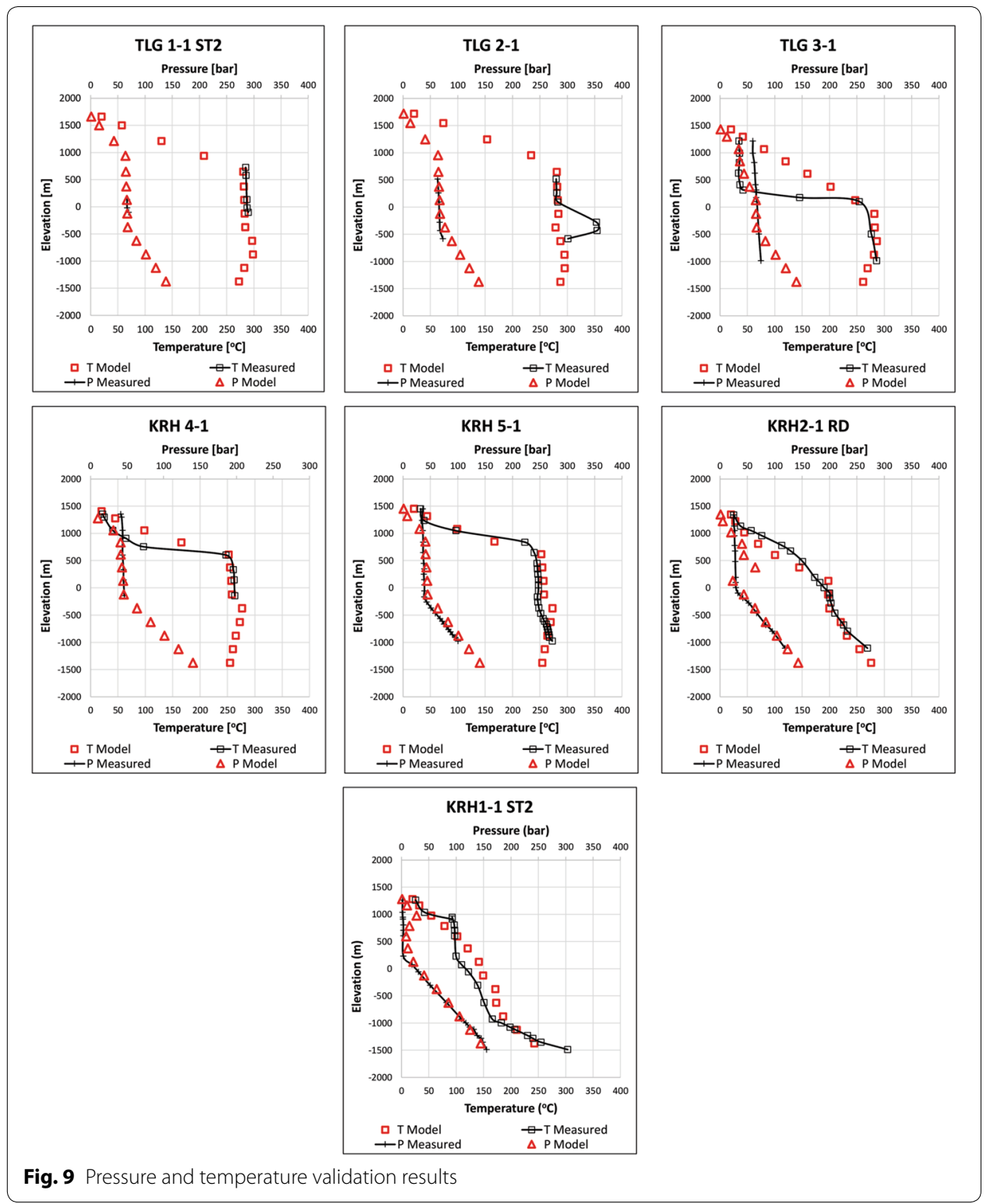

\section{Pressure and temperature matching}

The pressure and temperature of the model results are validated by comparing the measurement data of three wells in Talaga area (TLG 1-1, TLG 2-1, TLG 3-1) and four wells in Karaha area (KRH 1-1, KRH 2-1, KRH 4-1, KRH 5-1). Figure 9 shows a comparison between the model and measured data. It also shows a prediction of deeper reservoir pressure and temperature profile. The results of the matching of both pressure and temperature models showed good results compared to the data of seven wells. The model has been able to reproduce a shallow steam zone and deep brine reservoir. The pressure and temperature in the shallow reservoir show as steam static pressure and convective temperature profile near temperature saturation which is indicative of a steam-dominated reservoir. The steam static pressure in the vapor reservoir occurred due to the equilibrium mass flux of steam moving up and water as the condensed steam going 


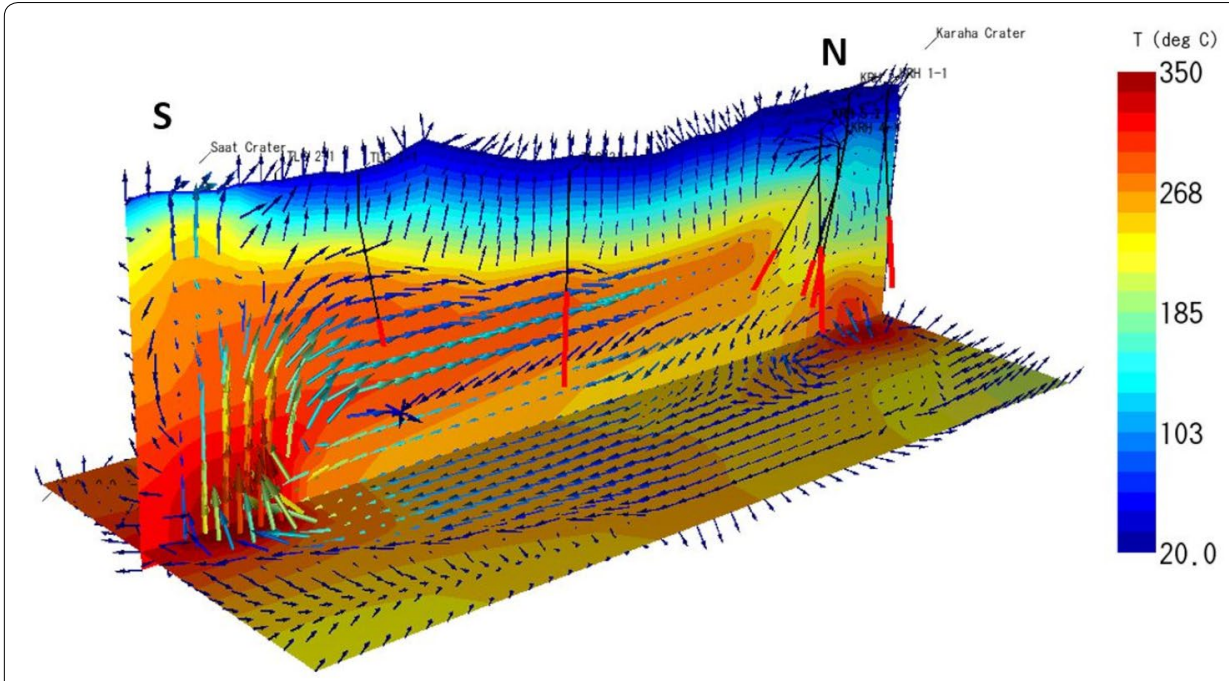

Fig. 10 Heat flow model

down. The steam reservoir pressure in the south area ( \pm 50 bar) is higher than the common reservoir pressure of vapor-dominated 30-40 bar (Allis et al. 2000). The pressure and temperature in the deep brine reservoir show a hydrostatic pressure and conductive temperature profile below temperature saturation which indicates a liquid-dominated reservoir.

\section{Heat and fluid flow direction}

Based on the existing conceptual model, which is shown in Fig. 5, the heat source is in the southern area beneath Saat Crater and Talaga Bodas Lake. The heat moves from the upflow area to the northern region, as well as the steam zone has been formed in the shallow depth of the upflow area and extends from the Talaga Bodas area to Karaha or the northern part where it thinned to the north. Figure 10 shows a temperature and heat flow model in a south-north cross section. The results show that the model has been able to describe the heat and fluid flow direction and the area of the steam zone similar to the conceptual model of Allis et al. (2000).

There are some flow paths from the deep reservoir flowing towards the heat source which represents deep recharge from the basement of the reservoir rock. The results of the natural state model have shown convective heat transfer indicated by the direction of the circular flow.

There is heat anomaly in the northern area beneath KRH 1-1 and KRH 2-1, it occurred due to deep mass recharge as seen in the model. High-temperature inflow to the reservoir may represent a heat source in the northernmost of Karaha that controls pressure and temperature in both of KRH 1-1 and KRH 2-1 wells. The presence of the heat source in the northernmost portion of the model may update the previous conceptual model.

Steam cap forming is shown in Fig. 11. Heat transfer occurred from the heat source to the reservoir by conduction. Steam flow originating from the southern region which has a high temperature flows upward and then flows laterally and spreads in shallow depths to the north forming a steam cap. During steam upflow, some steam can escape 


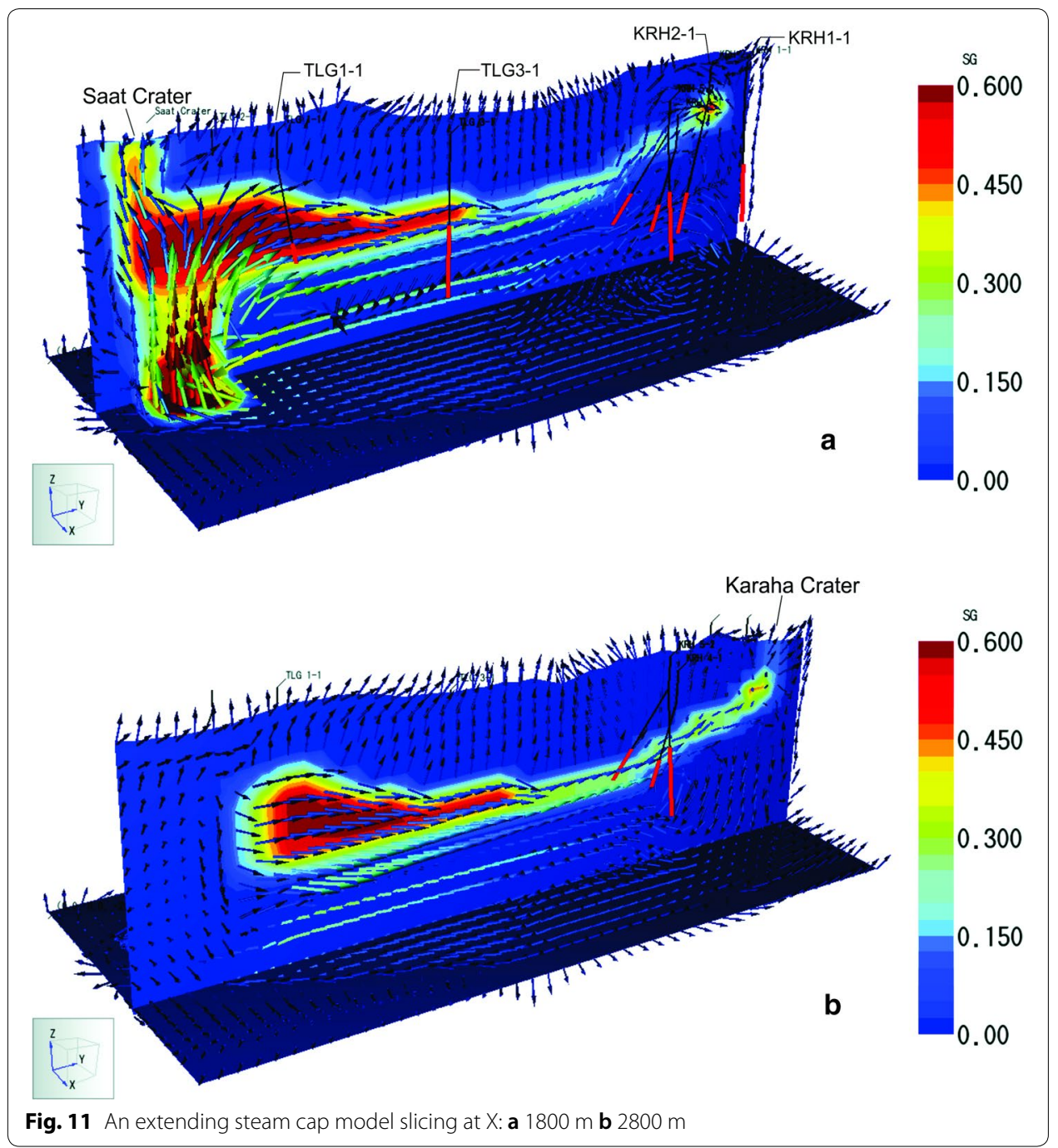

to the surface through a permeable opening layer as a thermal manifestation. Figure 11a shows a flowing upward of steam, which comes through Saat Crater, this upward stream formed the magmatic vapor chimney from a heat source to the surface. The challenge of this model is to reveal the steam cap underlying the brine reservoir and keep the steam cap extending to the north. Figure 11b shows a horizontally extending steam cap where the northernmost portion of the model shows a steam stream seeping through a fault that controlled the presence of thermal manifestation in the northern area.

In the northern area, steam moves up until it hits the caprock layer. The steam cannot flow upward due to the impermeable characteristic of the caprock. Heat is lost through the caprock, some of the steam would be condensed and goes down due to the influence of gravity. It represents the counter-flow heat transfer mechanism. When boiling occurs, water and steam are segregated by gravity as a result of the steam zone above the liquid zone. The rapidity of the segregation is controlled by high vertical permeability rock in the reservoir and the higher temperature range of boiling zone. 


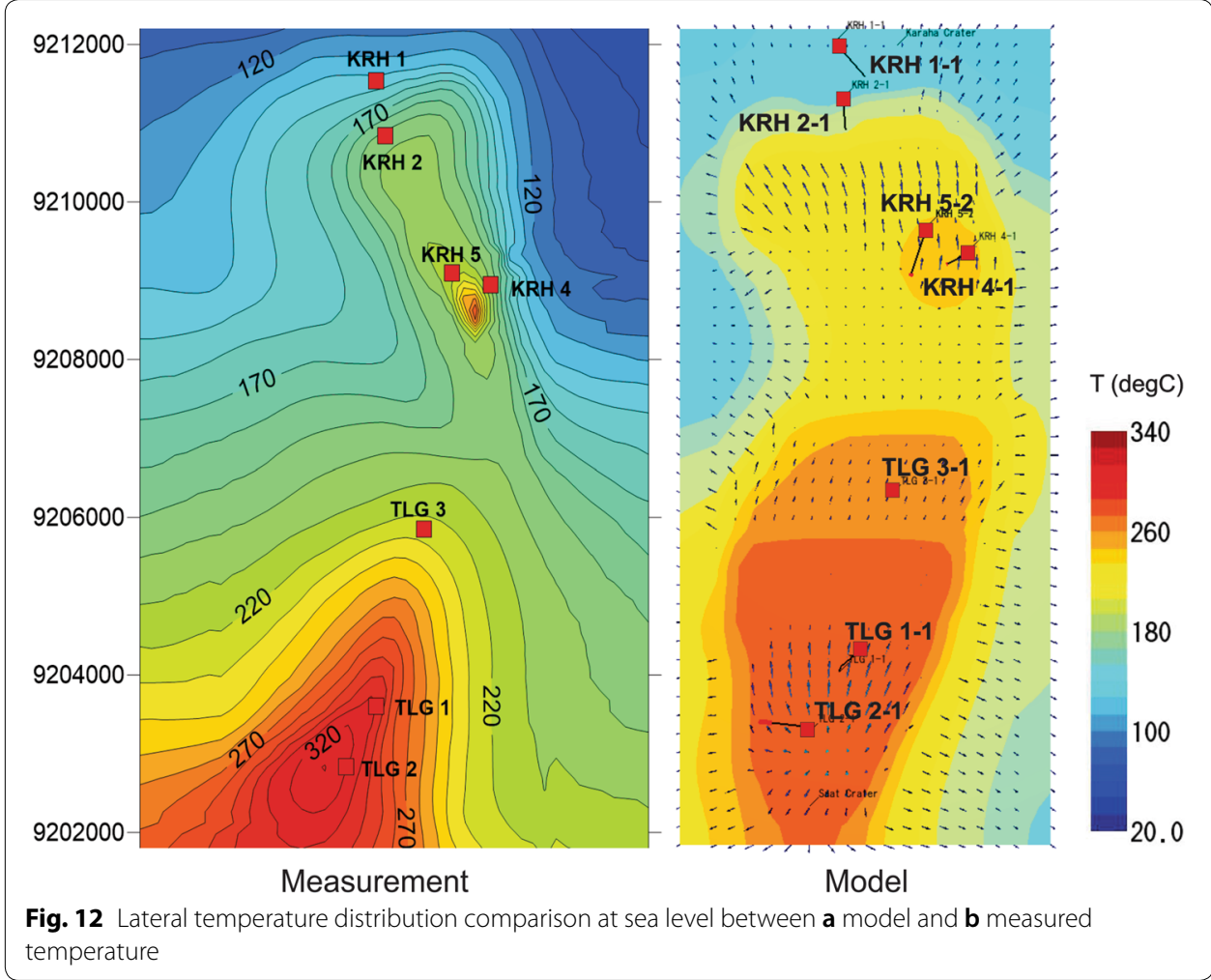

In the steam-dominated reservoir, steam occupies fracture space and water occupies matrix space. The amount of water mass is much greater than the steam mass, but it is in immobile condition. This model has a steam saturation value to the range of 0.2-0.6. As a comparison with similar vapor-dominated reservoir models, Pratama and Saptadji (2016) have developed a synthetic two-phase reservoir model with the result of average steam saturation value of 0.8 , while Ashat et al. (2019) have built a vapor-dominated model of Ciwidey-Patuha field that has a steam cap underlying a deep liquid reservoir with an average steam saturation value of 0.65 .

Comparison of the temperature distribution of the model results and from the measurement of wells in the depth of sea level shows the same pattern among them (see Fig. 12). The result shows that the model is similar in lateral temperature distribution compared with the actual measured temperature. In the center of Karaha area temperature goes up to around KRH 4 and KRH 5 due to the high permeability around these wells. The northernmost area has a low permeability which is indicated by temperature decreasing to the north.

\section{Resource assessment}

Experimental Design (ED) and Response Surface Methods (RSM) are systematic approaches for simulating the sensitivity study of reservoir parameters to the results of resource assessment. The ED and RSM algorithms have been developed to get a surface response or proxy equation with the objective function is the amount of electricity that can be generated. The ED method was first applied to oil and gas fields to predict the improvement in production performance (Faidi et al. 1996; Dejean and Blanc 1999; 
Elk et al. 2000). The application of ED method was begun in the geothermal industry to assess the amount of resources (Quinao and Zarrouk 2014, 2015, 2018; Pasikki et al. 2016; Ashat and Pratama 2017) and characterize reservoir parameters in the steamdominated field (Rachman 2016).

The succeeding resource assessments are based on the following assumption. The production wells were produced at a wellhead pressure of 10 bar with the productivity index of $2.5 \mathrm{E}-12 \mathrm{~m}^{3}$ which refers to the maximum productivity index value from the production test result. The power capacity generated from the model is calculated using an equation that describes the relationship between the production of accumulated steam and steam needed to generate each $\mathrm{MW}_{\mathrm{e}}$ during the development period (Quinao and Zarrouk 2015; Ashat and Pratama 2017):

$$
\mathrm{MW}_{\mathrm{e}}=\sum_{i=1}^{L} \frac{m_{\mathrm{si}} \times \Delta t_{i}}{L \times \mathrm{SSC}},
$$

where $\mathrm{MW}_{\mathrm{e}}$ is the power capacity, $m_{\mathrm{si}}$ is steam produced $(\mathrm{kg} / \mathrm{s}), \Delta t$ is delta time at simulator (years), $L$ is time project (years), and SSC is specific steam consumption $(\mathrm{kg} / \mathrm{s} /$ $\mathrm{MW})$. The theoretical SSC is $2.1 \mathrm{~kg} / \mathrm{s} / \mathrm{MW}$ which was based on the power output for a steam turbine calculated using the following equation (Cengel et al. 2008):

$$
\begin{aligned}
& W_{\mathrm{st}}=\eta_{\mathrm{t}} \times \eta_{\mathrm{g}} \times m_{\mathrm{s}} \times \Delta h, \\
& S S C=\frac{m_{s}}{W_{s t}}=\frac{1}{\eta_{t} \times \eta_{g} \times \Delta h},
\end{aligned}
$$

where $W_{\text {st }}$ is the steam turbine power output $\left(\mathrm{MW}_{\mathrm{e}}\right), \eta_{\mathrm{t}}$ is the isentropic turbine efficiency, $\eta_{\mathrm{g}}$ is the generator efficiency, and $\Delta h$ is the enthalpy difference between the turbine inlets and outlets $(\mathrm{kJ} / \mathrm{kg})$.

When the model reservoir has already been validated in its natural state condition, the ED parameter screening process is carried out. Five parameters, such as permeability, porosity, water saturation, density, the thickness of feed zone, were selected that influence electricity generation and these parameters have no significant effect on the natural state condition. The minimum and maximum values of each input parameter used in the simulation are presented in Table 4.

An ED full factorial design with five uncertain parameters $(n=5)$ at two levels (low $[-1]$ and high [1]) was used to identify the parameters which have significant effect on the amount of power generation. We used 35 production wells which were distributed in the center of the development plan area as shown in Fig. 13. The number of cases needed for an ED full factorial is $2^{n}$ or 32 simulations with 30 years of production. 32 ED full factorial model design generated using Minitab software is shown in Table 5.

The results of electric power generation show that the minimum and maximum power capacities are $106 \mathrm{MW}$ and $142 \mathrm{MW}$, respectively, as presented in Table 5. Analysis of the response surface or proxy model equation of the full factorial model $\operatorname{Power}_{(\mathrm{FF})}$ equation is shown in Eq. (4). This equation is used to determine a power capacity that can be generated from the model as a function of the five uncertain parameters and the coefficient of each uncertain parameter was obtained from the multivariate regression process: 
Table 4 Uncertain parameters to be tested on the K-TB model using the ED and RSM workflow of full factorial/Plackett-Burman

\begin{tabular}{lll}
\hline Parameter & Low $(\mathbf{- 1 )}$ & High (1) \\
\hline Permeability $(\mathrm{mD}), k_{x y z}$ & $-20 \%$ base & $+20 \%$ base \\
Matrix porosity $(-), \varphi$ & $-20 \%$ base & $+20 \%$ base \\
Water saturation $(-)$, SW & 0.3 & 0.5 \\
Density $\left(\mathrm{kg} / \mathrm{m}^{3}\right), \rho$ & 2500 & 2700 \\
Feed zone $(\mathrm{m}), \mathrm{FZ}$ & -250 & -500 \\
\hline
\end{tabular}

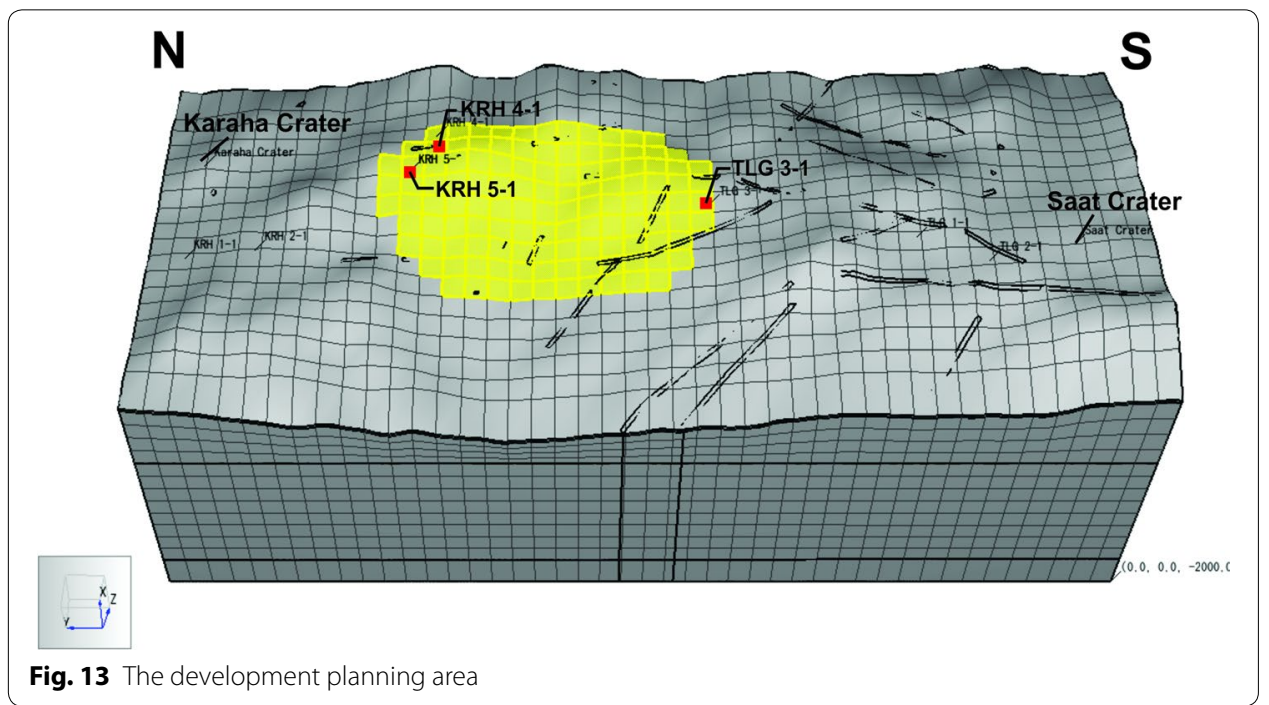

$$
\begin{array}{rl}
\text { Power }_{\mathrm{FF}}=12 & 2.8+6.8 * k_{x y z}-2.1 * \phi+5.6 \mathrm{SW}+1.2 * \rho-0.1 * \mathrm{FZ}+0.2 k_{x y z} * \phi \\
& +0.3 k_{x y z} * \mathrm{SW}+0.1 k_{x y z} * \rho+1.7 * k_{x y z} * \mathrm{FZ}+0.3 \phi * \mathrm{SW}+0.2 \phi * \rho-0.6 \phi * \mathrm{FZ} \\
& +0.2 \mathrm{SW} * \rho-0.4 \mathrm{SW} * \mathrm{FZ}+0.1 \rho * \mathrm{FZ}+0.3 k_{x y z} * \phi * \mathrm{SW}-0.5 k_{x y z} * \phi * \rho-0.6 k_{x y z} \\
& * \phi * \mathrm{FZ}+0.2 k_{x y z} * \mathrm{SW} * \rho+0.6 k_{x y z} * \mathrm{SW} * \mathrm{FZ}+0.3 k_{x y z} * \rho * \mathrm{FZ}+0.4 \phi * \mathrm{SW} * \rho \\
& -0.7 \phi * \mathrm{SW} * \mathrm{FZ}+0.2 \phi * \rho * \mathrm{FZ}+0.2 \mathrm{SW} * \rho * \mathrm{FZ}+0.4 k_{x y z} * \phi * \mathrm{SW} * \rho-0.1 * k_{x y z} \\
& * \phi * \mathrm{SW} * \mathrm{FZ}-0.5 * k_{x y z} * \phi * \rho * \mathrm{FZ}+0.02 k_{x y z} * \mathrm{SW} * \rho * \mathrm{FZ}+0.4 \phi * \mathrm{SW} * \rho * \mathrm{FZ} \\
& +0.3 k_{x y z} * \phi * \mathrm{SW} * \rho * \mathrm{FZ} .
\end{array}
$$

An ED Plackett-Burman design with five uncertain parameters $(n=5)$ is compared with the results of ED full factorial. The number of cases needed for ED Plackett-Burman is 12 simulations and the result of electric power generation is presented in Table 6 . Proxy equation of ED Plackett-Burman models ( Power $_{\mathrm{PB}}$ ) is shown in the following equation:

$$
\text { Power }_{\mathrm{PB}}=121.0+6.3 * k_{x y z}-1.7 * \phi+4.7 * \mathrm{SW}+0.8 * \rho-0.7 * \mathrm{FZ} .
$$

Then the Monte Carlo simulation is carried out using the proxy models of Eqs. (4) and (5) with 50,000 iterations. The comparison of the histogram and cumulative frequency distribution curve of power capacity between full factorial ( Power $_{\mathrm{FF}}$ ) and Plackett-Burman (Power ${ }_{\mathrm{PB}}$ ) is depicted in Fig. 14. The power capacity obtained from Plackett-Burman design shows the good result with a determination coefficient $\left(R^{2}\right)$ of $94.7 \%$ for 12 runs, while full factorial design obtained $R^{2}$ exactly $100 \%$. Overall results, 
Table 5 K-TB reservoir numerical model results to full factorial design results for five parameters at two levels

\begin{tabular}{|c|c|c|c|c|c|c|}
\hline Run order & $k_{x y z}$ & $\phi$ & sw & $\rho$ & $\mathrm{FZ}$ & Power (MW) \\
\hline 1 & 1 & -1 & -1 & -1 & -1 & 123 \\
\hline 2 & 1 & 1 & 1 & -1 & -1 & 133 \\
\hline 3 & 1 & -1 & -1 & 1 & -1 & 125 \\
\hline 4 & 1 & 1 & 1 & 1 & 1 & 137 \\
\hline 5 & -1 & 1 & 1 & -1 & 1 & 113 \\
\hline 6 & -1 & 1 & 1 & 1 & -1 & 123 \\
\hline 7 & 1 & -1 & 1 & -1 & -1 & 132 \\
\hline 8 & 1 & -1 & 1 & -1 & 1 & 139 \\
\hline 9 & -1 & -1 & -1 & 1 & -1 & 116 \\
\hline 10 & -1 & -1 & 1 & -1 & -1 & 124 \\
\hline 11 & 1 & 1 & -1 & -1 & 1 & 123 \\
\hline 12 & 1 & -1 & 1 & 1 & -1 & 134 \\
\hline 13 & 1 & 1 & 1 & -1 & 1 & 131 \\
\hline 14 & 1 & 1 & -1 & 1 & 1 & 121 \\
\hline 15 & 1 & -1 & -1 & -1 & 1 & 125 \\
\hline 16 & 1 & 1 & 1 & 1 & -1 & 136 \\
\hline 17 & -1 & -1 & -1 & -1 & 1 & 112 \\
\hline 18 & 1 & 1 & -1 & 1 & -1 & 121 \\
\hline 19 & -1 & -1 & -1 & -1 & -1 & 113 \\
\hline 20 & 1 & -1 & 1 & 1 & 1 & 142 \\
\hline 21 & -1 & -1 & 1 & 1 & -1 & 127 \\
\hline 22 & 1 & 1 & -1 & -1 & -1 & 120 \\
\hline 23 & 1 & -1 & -1 & 1 & 1 & 131 \\
\hline 24 & -1 & -1 & -1 & 1 & 1 & 111 \\
\hline 25 & -1 & 1 & 1 & 1 & 1 & 118 \\
\hline 26 & -1 & 1 & -1 & 1 & 1 & 110 \\
\hline 27 & -1 & 1 & 1 & -1 & -1 & 121 \\
\hline 28 & -1 & 1 & -1 & 1 & -1 & 110 \\
\hline 29 & -1 & -1 & 1 & -1 & 1 & 122 \\
\hline 30 & -1 & 1 & -1 & -1 & 1 & 106 \\
\hline 31 & -1 & 1 & -1 & -1 & -1 & 107 \\
\hline 32 & -1 & -1 & 1 & 1 & 1 & 121 \\
\hline
\end{tabular}

Plackett-Burman method have been quite effective for performing power calculations with more efficient run counts and less run time. The result shows that ED full factorial and Plackett-Burman based on the numerical model, and the K-TB field can support power generation for 30 years with the power capacity for P10, P50, and P90 as $115 \mathrm{MW}$, $120 \mathrm{MW}$, and $125 \mathrm{MW}$, respectively. Therefore, the development scenario in the reservoir modelling limited up to $125 \mathrm{MW}$.

\section{Development scenarios}

The $\mathrm{K}-\mathrm{TB}$ reservoir has a thick steam zone at shallow depths which is thinning towards the area of Karaha. The production would be made by utilizing a steam zone as the main production, while make-up well strategy was placed in the steam zone or water zone. 
Table 6 K-TB reservoir numerical model results to the Plackett-Burman designed simulation experiments

\begin{tabular}{lrrrrrl}
\hline Run order & $\boldsymbol{k}_{\mathbf{x y z}}$ & $\boldsymbol{\phi}$ & $\mathbf{S W}$ & $\boldsymbol{\rho}$ & $\mathbf{F Z}$ & Power (MWe) \\
\hline 1 & -1 & -1 & -1 & -1 & -1 & 113 \\
2 & -1 & -1 & 1 & 1 & 1 & 121 \\
3 & 1 & -1 & -1 & -1 & 1 & 125 \\
4 & -1 & -1 & -1 & 1 & 1 & 111 \\
5 & 1 & 1 & -1 & 1 & 1 & 121 \\
6 & -1 & 1 & -1 & -1 & -1 & 107 \\
7 & 1 & 1 & -1 & 1 & -1 & 121 \\
8 & 1 & -1 & 1 & 1 & -1 & 134 \\
9 & -1 & 1 & 1 & 1 & -1 & 123 \\
10 & 1 & 1 & 1 & -1 & 1 & 131 \\
11 & -1 & 1 & 1 & -1 & 1 & 113 \\
12 & 1 & -1 & 1 & -1 & -1 & 132 \\
\hline
\end{tabular}

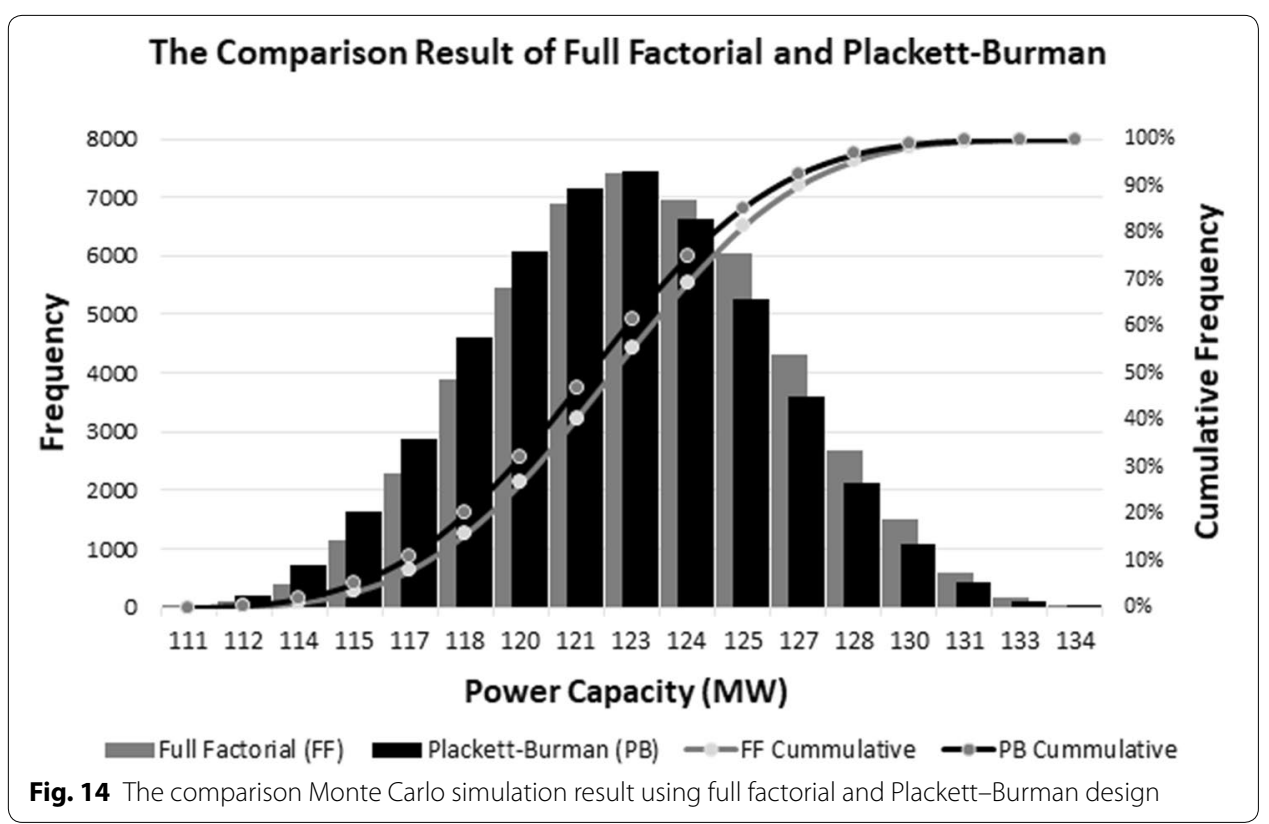

The best strategy was chosen based on production sustainability and the minimum pressure and temperature changes that occur within a reservoir.

Development is carried out by utilizing existing productive wells and by drilling new production wells in the middle of the development area (Fig. 13). The development scenario in this study refers to the results of previous resource calculations. This work applied two production scenario strategies of $60 \mathrm{MW}$ and $110 \mathrm{MW}$ with exploitation period is 30 years.

The assumptions of forecasting production are productivity index calibration of existing wells is used as a reference for additional of production and make-up wells as well as the estimated potential of new wells at $7 \mathrm{MW} /$ well, injection well capacity of 200 tons/h, injection wells are divided into brine and condensate injection well type, initial 


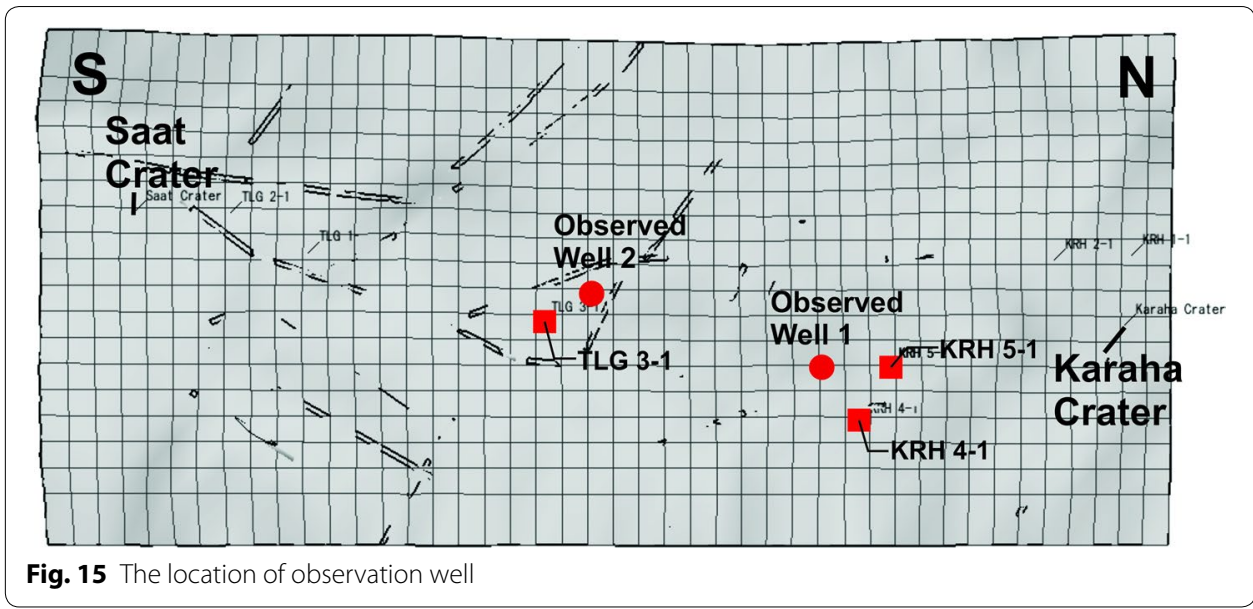

production strategy is focused on steam reservoir zones, and reinjection strategy is carried out centrally on the northern part of the model.

The aim of the selection of the reinjection strategy is to achieve and to maintain the sustainability of electricity production (Kaya and O'Sullivan 2010; Goyal and Conant 2010; Fuzhi et al. 2015). The reinjection strategy has several different effects on each system depending on several conditions, such as initial thermodynamic state of the reservoir (Stefansson 1997), location and local geological structure (Diaz et al. 2016). In this case, the injection target area is located inside the northern area and it is also located at deeper depth to accommodate enough fluid recharge, pressure support and the retaining time of injected fluid to heat up to minimize the thermal breakthrough (Axelsson 2012).

The K-TB power plant system used in this study is the separated steam cycle based on the characteristic of fluid production in the wellhead and enthalpy reservoir. The wellhead pressure, separator pressure, condenser pressure, turbine efficiency is 10 bar, 7.5 bar, 6 bar, and 0.08 bar, 80\%, respectively. The specific steam consumption for both $60 \mathrm{MW}$ and $110 \mathrm{MW}$ is $7.7 \mathrm{ton} / \mathrm{h} / \mathrm{MW}$. Therefore, the steam requirement for $60 \mathrm{MW}$ is 462 tons/h and for $110 \mathrm{MW}$ is 847 tons/h. Hence, to maintain the minimum requirement of steam supply, the model had been applied to a make-up well using well deliverability method. Two target make-up well strategies are produced from the steam zone or brain reservoir zone. The aim of the development strategy is to understand the performance of reservoir pressure under exploitation.

The reservoir monitoring was performed on observation wells 1 and 2 with it marked with red dots as shown in Fig. 15. The pressure and temperature changes that occurred during the production of $60 \mathrm{MW}$ are shown in Fig. 16. From the observation wells, the pressure and temperature in the steam reservoir experienced a decrease in both scenarios for the placement of make-up wells ranging between 6 and 17 bar and $14{ }^{\circ} \mathrm{C}$, respectively, while in the brine reservoir, the pressure drop ranged from 10 to $16 \mathrm{bar}$, and the reservoir temperature at the water zone is relatively stable with a decrease of $2{ }^{\circ} \mathrm{C}$ for 30 years. The largest decrease in both placement scenarios of makeup wells occurred in water zones. The total wells required for $60 \mathrm{MW}$ of the contractual time are shown in Table 7, which was the number of make-up wells in the water zone required in about $50 \%$ less than make-up wells in the steam zone. 


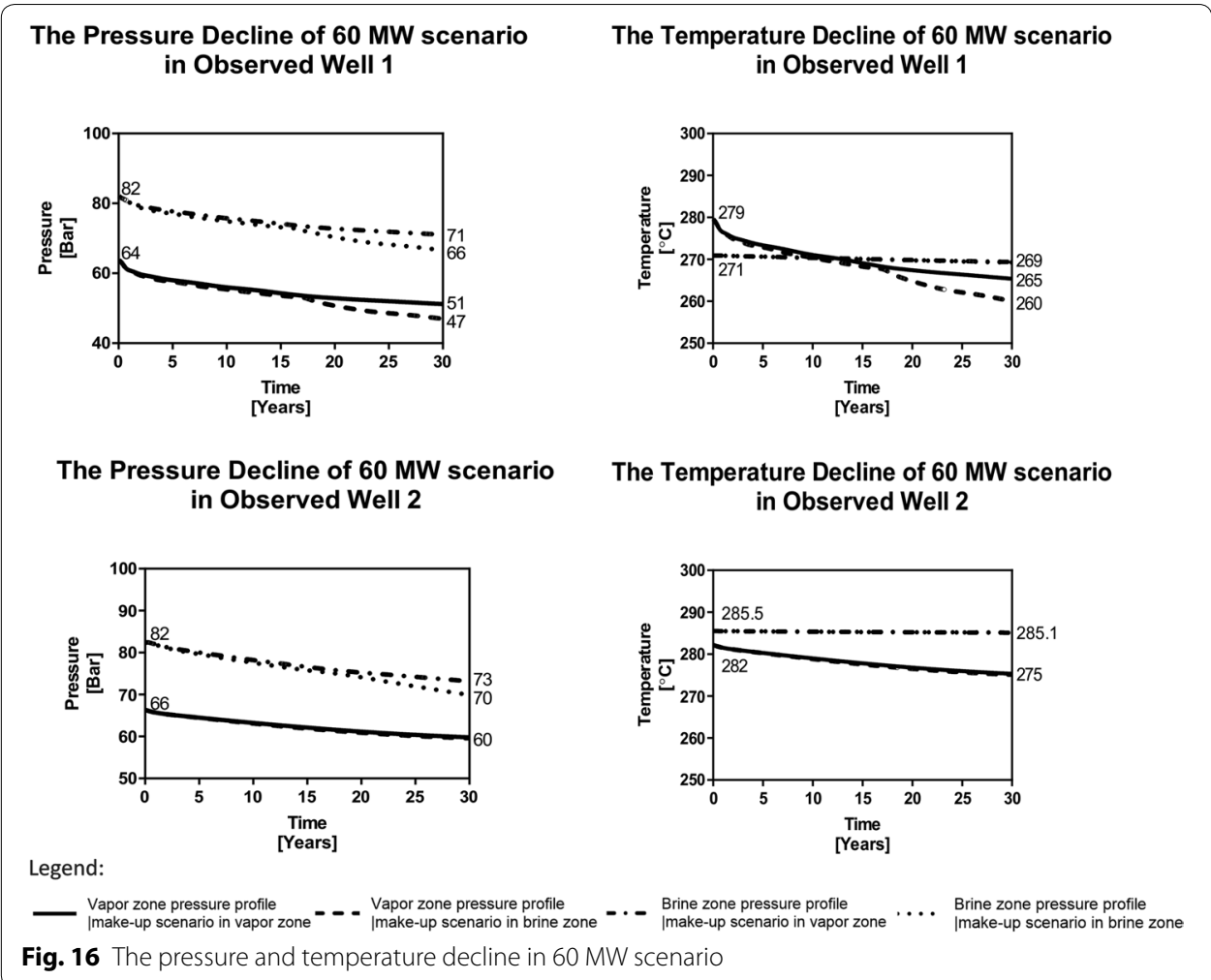

Table 7 Total wells needed for $60 \mathrm{MW}$ of $\mathbf{3 0}$ years production

\begin{tabular}{llll}
\hline Make up well strategy & \multicolumn{4}{l}{$\mathbf{6 0}$ MWe production capacity } \\
\cline { 2 - 4 } & No. of make-up wells & No. of production well & Total well \\
\hline Two-phase (mix) & 2 & 11 & 13 \\
Steam zone & 4 & 11 & 15 \\
\hline
\end{tabular}

The changes in pressure and temperature occurring in a $110 \mathrm{MW}$ scenario are shown in Fig. 17. From the observation wells, the overall steam reservoir pressure and temperature decreased from both placement scenarios comprising $13-23$ bar and $18-24{ }^{\circ} \mathrm{C}$ for 30 years, while the pressure and temperature drop in the deep liquid reservoir ranged from 17 to 22 bar and $2-5{ }^{\circ} \mathrm{C}$ for 30 years. The total wells required for $110 \mathrm{MW}$ of 30-year production are shown in Table 8. The number of make-up wells in the water zone and the steam zone is 9 and 22, respectively.

The best results come from the placement strategy make-up wells in contrast to the Pratama and Saptadji (2017), where the best make-up wells are the steam zone and the primary production in the reservoir brine. Nevertheless, the production of mass and fluid of the reservoir two phase with steam zone underlying brine reservoir should have equilibrium from the steam zone and brine reservoir to reach a sustainable production. 
The Pressure Decline of 110 MW scenario in Observed Well 1

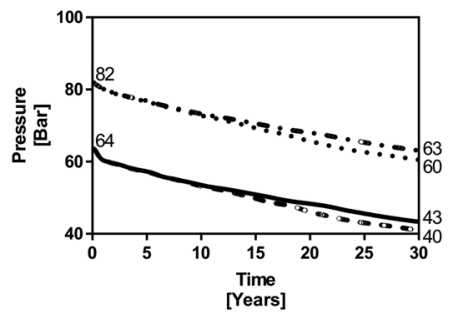

The Pressure Decline of 110 MW scenario in Observed Well 2

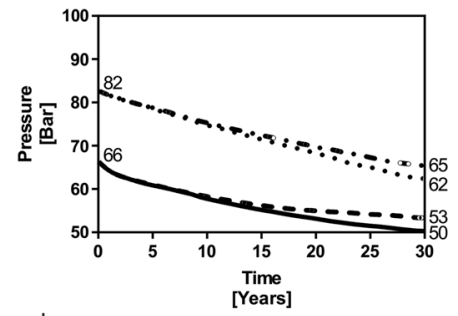

The Temperature Decline of 110 MW scenario in Observed Well 1

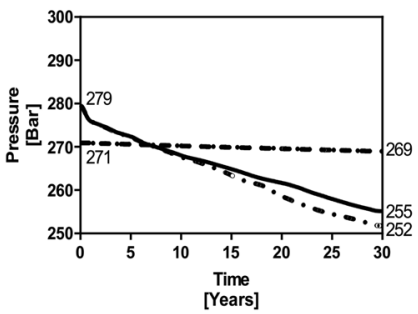

The Temperature Decline of 110 MW scenario in Observed Well 2

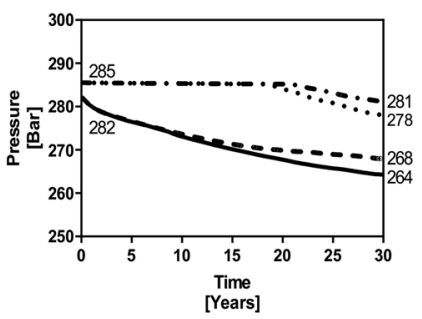

Legend:

Vapor zone pressure profile _ _ - Vapor zone pressure profile Brine zone pressure profile make-up scenario in vapor zon

Fig. 17 The pressure and temperature decline in $110 \mathrm{MW}$ scenario

Table 8 Total wells needed for $110 \mathrm{MW}$ of 30 years production

\begin{tabular}{llcl}
\hline Make up well strategy & \multicolumn{2}{l}{$\mathbf{1 1 0}$ MWe production capacity } \\
\cline { 2 - 4 } & No. of make-up wells & No. of production well & Total well \\
\hline Two-phase (mix) & 9 & 19 & 28 \\
Steam zone & 22 & 19 & 41 \\
\hline
\end{tabular}

\section{Conclusion}

The numerical model of the K-TB geothermal field that has a steam reservoir above a brine reservoir has been successfully established. The model aligns well with actual pressure and temperature data of seven wells and the conceptual model of the field. Based on the simulation results, deep mass recharge in the north area which is located below Kawah Karaha of the model is needed to control the pressure and well temperature of the north of the model.

The magnitude of most likely power that can be generated by this model is $120 \mathrm{MW}$ (P50). The KTB model indicates it has enough steam for 30 years of production with a maximum development capacity of $110 \mathrm{MW}$.

Based on the forecasting results of two development scenarios at $60 \mathrm{MW}$ and $110 \mathrm{MW}$, the placement of make-up wells in the two-phase zone needs fewer wells than in the steam zone. The best development scenario is $60 \mathrm{MW}$ with a make-up well placement strategy in the water zone and the number of wells needed for production, injection and 
make-up is 11,3 and 2, respectively. The pressure and temperature drops that occur are $0.2-0.6 \mathrm{bar} /$ year and $2-4{ }^{\circ} \mathrm{C}$ for 30 -year production.

\section{Acknowledgements}

The TOUGH2 simulator was supported by Project for Technology Development of Steam-spot Detection and Sustainable Resource Use for Large Enhancement of Geothermal Power Generation in Indonesia, Beneficial and Advanced Geothermal Use System (BAGUS) - Science and Technology Research Partnership for Sustainable Development (SATREPS) Institut Teknologi Bandung - Kyoto University. This research was patially.

\section{Authors' contributions}

TWP built the models discussed and ran all simulations as well as drafted the manuscript as part of his master thesis. STP and $\mathrm{HBP}$ supervised the research and guided the interpretation of results, provided guidance and insight in evaluating the results and helped draft the manuscript. STP and HBP considerably edited and improved the draft. All authors read and approved the final manuscript.

\section{Funding}

The research was supported by P3MI (Program Penelitian, Pengabdian Masyarakat, dan Inovasi [Research, Community Service and Innovation Program]) Reservoir Engineering Research Group ITB ITB.

\section{Availability of data and materials}

All relevant data and material are presented in the main paper.

\section{Consent for publication}

Not applicable.

Competing interests

The authors declare that they have no competing interests.

\section{Author details}

${ }^{1}$ Geothermal Engineering Master Program, Institut Teknologi Bandung, Jl. Ganesha 10, Bandung 40132, Indonesia. ${ }^{2}$ Geothermal Research Group, Institut Teknologi Bandung, J. Ganesha 10, Bandung 40132, Indonesia.

Received: 14 August 2018 Accepted: 30 July 2019

Published online: 07 August 2019

\section{References}

Allis R, Moore JN. Evolution of volcano-hosted vapor-dominated geothermal systems. Geotherm Resour Council Trans. 2000;24:211-6.

Allis R, Moore JN, McCulloch J, Petty S, DeRocher T. Karaha-Talaga Bodas, Indonesia: a partially vapor-dominated geothermal system. Geotherm Resour Council Trans. 2000;24:217-22.

Armannsson H. Geochemical aspects of geothermal utilization. Compr Renew Energy. 2012;7:95-168.

Ashat A, Pratama HB. Application of experimental design in geothermal resources assessment of Ciwidey-Patuha, West Java, Indonesia. In: IOP conference series: earth and environmental science 103, Bandung, Indonesia; 2017.

Ashat A, Pratama HB, Itoi R. Updating conceptual model of Ciwidey-Patuha geothermal using dynamic numerical model. In: IOP conference series: earth and environmental science 254, Bandung, Indonesia; 2019.

Axelsson G. Role and management of geothermal reinjection. Reykjavik: United Nations University-Geothermal Training Program; 2012.

Brehme M, Blocher G, Cacace M, Deon F, Moeck I, Wiegand B, Kamah Y, Regenspurg S, Zimmermann G, Sauter M, Huenges E. Characterizing permeability structures in geothermal reservoirs: a case study in Lahendong. In: Proceedings 41st workshop on geothermal reservoir engineering, Stanford University; 2016.

Bronto S. Volcanic geology of Galunggung, west java, Indonesia. Ph.D. thesis, University of Canterbury, 1989.

Budhitrisna T. Geological map of Tasikmalaya. Tech. rep. Bandung: Pusat Penelitian dan Pengembangan Geologi; 1986.

Cengel YA, Turner RH, Cimbala JM. Fundamentals of thermal-fluid sciences. 3rd ed. USA: McGraw-Hill; 2008.

Dejean JP, Blanc G. Managing uncertainties on production predictions using integrated statistical methods. In: Proceeding the SPE annual technical conference and exhibition, 3-6 October, Houston, Texas; 1999.

Diaz AR, Kaya E, Zarrouk SJ. Reinjection in geothermal fields—a worldwide review update. Renew Sustain Energy Rev. 2016;53:105-62.

Dilley LM, Moore J. Fluid inclusion gas compositions of an evolving vapor dominated geothermal system at KarahaTalaga Bodas, Indonesia. In: Proceedings world geothermal congress, 19-25 April, Melbourne, Australia; 2015.

Elk JF, Guerrera L, Vijayan K, Gupta R. Improved uncertainty management in field development studies through the application of the experimental design method to the multiple realizations approach. In: Proceeding the SPE annual technical conference and exhibition, 1-4 October, Dallas, Texas; 2000.

Faidi SA, Ponting DK, Eagling TL. Experimental design in interactive reservoir simulation. In: Proceeding the petroleum computer conference, 2-5 June, Dallas, Texas; 1996.

Fuzhi H, Shiyu S, Baiming Z. Geothermal resource and development in Tianjin of China. In: Proceedings world geothermal congress, 19-25 April, Melbourne, Australia; 2015.

GeothermEx. Assessment of the geothermal resource in the Karaha Talaga Bodas area. Tech. rep. California: GeothermEx; 1998.

Goyal KP, Conant TT. Performance history of the Geysers steam field, California, USA. Geothermics. 2010;39:321-8. 
Kaya E, O'Sullivan MJ. Reinjection at Wairakei Tauhara geothermal field. In: Proceedings 17th Australasian fluid mechanics conference. Auckland, New Zealand; 2010.

Moore JN. The evolution of a partially vapor-dominated geothermal system at Karaha-Telaga Bodas, Indonesia: insights from mineral distributions and UID inclusion measurements. In: Proceedings NZ geothermal workshop. Auckland. New Zealand; 2012.

Moore JN, Lutz SJ, Renner JL, McCulloch J, Petty S. Evolution of a volcanic-vosted vapor-dominated system: petrologic and geochemical data from core hole T-8, Karaha-Telaga Bodas, Indonesia. Geotherm Resour Council Trans. 2000;24:259-63.

Moore JN, Allis R, Renner JL, Mildenhall D, McCulloch J. Petrologic evidence for boiling to dryness in the Karaha-Talaga Bodas geothermal system, Indonesia. In: Proceedings 27th workshop on geothermal reservoir engineering. Stanford University, California; 2002a.

Moore JN, Christenson B, Browne PRL, Lutz SJ. The mineralogic consequences and behavior of descending sulfate waters: an example from the Karaha-Talaga Bodas geothermal system, Indonesia. In: Proceedings 27th workshop on geothermal reservoir engineering. Stanford University, California; 2002b.

Moore JN, Norman DI, Allis R. Geochemical evolution of the vapor dominated regime at Karaha-Talaga Bodas, Indonesia: insight from uid gas compositions. In: Proceedings 24th NZ geothermal workshop. Auckland, New Zealand; 2002c.

Moore JN, Allis R, Norman D. New insights into the time-temperature-composition history of the volcanic-hosted geothermal system at Karaha-Telaga-Bodas, Indonesia. Geotherm Resour Council Trans. 2003;27:319-23.

Moore JN, Christenson B, Allis R, Browne PRL, Lutz SJ. The mineralogical consequences and behavior of descending acid-sulfate waters: an example from the Karaha-Telaga Bodas geothermal system, Indonesia. Can Miner. 2004:42:1483-99.

Moore JN, Allis RG, Nemcok M, Powell TS, Bruton CJ, Wannamaker PE, Raharjo IB, Norman DI. The evolution of volcanohosted geothermal systems based on deep wells from Karaha-Telaga Bodas, Indonesia. Am J Sci. 2008;308:1-48.

Nemcok M, McCulloch J, Nash G, Moore J. Fault kinematics in the Karaha-Telaga Bodas, Indonesia, geothermal field: an interpretation tool for remote sensing data. Geotherm Resour Council Trans. 2001;25:411-5.

Nemcok M, Moore JN, Allis R, McCulloch J. Fracture development within a stratovolcano: The Karaha-Telaga Bodas geothermal field, Java volcanic arc. Geol Soc. 2004;231:223-42.

Nemcok M, Moore JN, Christensen C, Allis R, Powell T, Murray B, Nash G. Controls on the Karaha-Talaga Bodas geothermal reservoir. Geothermics. 2007;36:9-46.

Nicholson K. Geothermal fluids: chemistry and exploration techniques. Berlin: Springer-Verlag; 1993.

Omagbon J, O'Sullivan MJ. Use of a heuristic method and PEST for calibration of geothermal models. In: Proceedings 33rd NZ geothermal workshop. Auckland. New Zealand; 2011.

Pasikki RG, Cita F, Hernawan A. Application of experimental design (ED) in geothermal greenfield size assessment. In: Proceedings the 4th Indonesia international geothermal convention \& exhibition, Jakarta, Indonesia; 2016.

Perez-Flores P, Wang G, Mitchell TM, Meredith PG, Nara Y, Sarkar V, Cembrano J. The effect of offset on fracture permeability of rocks from the Southern Andes volcanic zone, Chile. J Struct Geol. 2017;104:142-58.

Powell T, Moore J, DeRocher J, McCulloch J. Reservoir geochemistry of the Karaha-Talaga Bodas prospect, Indonesia. Geotherm Resour Council Trans. 2001:25:363-7.

Pratama HB, Saptadji NM. Numerical simulation for natural state of two-phase liquid dominated geothermal reservoir with steam cap underlying brine reservoir. In: IOP conference series: earth and environmental science 42, Bandung, Indonesia; 2016.

Pratama HB, Saptadji NM. Study of sustainable production in two-phase liquid dominated with steam cap underlying brine reservoir by numerical simulation. In: IOP conference series: earth and environmental science 103, Bandung, Indonesia; 2017.

Pruess K, Oldenburg C, Moridis G. TOUGH2 User's Guide, Version 2.0. Lawrence Berkeley University Press, California; 1999.

Quinao JJ, Zarrouk SJ. Applications of experimental design and response surface method in probabilistic geothermal resource assessment—-preliminary results. In: Proceedings 39th workshop on geothermal reservoir engineering, Stanford University. California; 2014.

Quinao JJ, Zarrouk SJ. Application of experimental design and response surface methods in probabilistic geothermal resource assessment: numerical simulation and volumetric methods. In: Proceedings world geothermal congress, 19-25 April, Melbourne, Australia; 2015.

Quinao JJ, Zarrouk SJ. Geothermal resource assessment using experimental design and response surface methods: The Ngatamariki Geothermal field, New Zealand. Renew Energy. 2018;116:324-34.

Rachman RH. Application methods experimental design (Plackett-Burman) in uncertainty parameters reservoir vapour dominated. In: Proceedings 41st workshop on geothermal reservoir engineering, Stanford University. California; 2016.

Raharjo I, Wannamaker P, Allis R, Chapman D. Magnetotelluric interpretation of the Karaha Bodas geothermal field Indonesia. In: Proceedings 27th workshop on geothermal reservoir engineering, Stanford University. California; 2002

Stefansson V. Geothermal reinjection experience. Geothermics. 1997;26:99-130.

Strelbitskaya S, Khosrawi K, Porkhial S, Behrad Y. Fluid chemistry geothermal exploration wells at NW-Sabalan geothermal _eld, Iran. In: Proceedings world geothermal congress. Melbourne, Australia; 2015.

Sumantoro ZZ, Yeh A, O'Sullivan JP, O'Sullivan MJ. Reservoir modelling of Lahendong geothermal field, Sulawesi-Indonesia. In: Proceedings 37th NZ geothermal workshop, Taupo, New Zealand; 2015.

Tripp A, Moore J, Ussher G, McCulloch J. Gravity modeling of the Karaha-Talaga Bodas geothermal system, Indonesia. In: Proceedings 27th workshop on geothermal reservoir engineering. Stanford University. California; 2002.

Verma SP, Arias EF. Optimal discretization time and mesh size in three-dimensional temperature field simulation in two Mexican geothermal fields. Geothermics. 2014;51:91-102.

\section{Publisher's Note}

Springer Nature remains neutral with regard to jurisdictional claims in published maps and institutional affiliations. 